\title{
TMS 19 ÇALIŞANLARA SAĞLANAN FAYDALAR STANDARDI KAPSAMINDA TANIMLANMIŞ FAYDA PLANLARININ MUHASEBELEŞTIRILLMESI ${ }^{1}$
}

\author{
Yrd. Doç. Dr. Mehmet DURGUT ${ }^{*}$ \\ Doç. Dr. Uğur KAYA**
}

ÖZ

TMS 19 Çalışanlara Sağlanan Faydalar Standardl, işletmelerde çalışanlarla ilgili sağlanan kısa vadeli faydalar, işten ayrılma sonrası sağlanacak faydalar (tanımlanmış katkı ve fayda planları), diğer uzun vadeli faydalar ve işten çıkarma tazminatları olmak üzere dört faydaya yönelik düzenlemeler içermektedir. Standardın kapsamını sınırlamak amacıyla bu çalışmada söz konusu faydalardan, çalışma dönemi sonrası faydalar kapsamındaki tanımlanmış fayda planına yönelik ilke ve kurallar üzerinde durulmuştur. Bu çerçevede en çok bilinen fayda planı örneği kıdem tazminatının dışında kalan ve Türkiye için yeni uygulama niteliğinde olan tanımlanmış fayda planları gerek hesaplama ve gerekse kayıt bazında incelenmiş ve çeşitli önerilerde bulunulmuştur.

Anahtar Kelimeler: Muhasebe Standartları, Çalışanlara Să̆lanan Faydalar, Tanımlanmış Fayda Planlarl

Jel Sinıflandirmast: M40, M41, M48, M49

\section{ACCOUNTING FOR DEFINED BENEFITS PLANS ACCORDING TO IAS 19 EMPLOYE BENEFITS STANDARD}

\begin{abstract}
TMS 19 Employee Benefits Standard consists of regulations on four benefits including shortterm benefits of the employees in the establishments, post-employment benefits (defined contribution and benefit plans), other long-term benefits and termination benefits. In order to limit the scope of the standards the said standards and the policies for the defined benefit plan subject to the postemployment benefits have been mentioned in this study. In this context the most known benefit plan example, the defined benefit plans other than severance payment and which is a new application for Turkey have been analyzed on the basis of calculation and recording, and various suggestions have been made as well.

Keywords: Accounting Standards, Employee Benefits, Defined Benefit Plans

Jel Classification: M40, M41, M48, M49

\footnotetext{
${ }^{1}$ Bu çalışma Karadeniz Teknik Üniversitesi, Sosyal Bilimler Enstitüsü’nce kabul edilen “İnsan Kaynaklarına Yönelik Faaliyetlerin Türkiye Muhasebe Standartlarına Göre Muhasebeleştirilmesi ve Türkiye deki Uygulama Boyutu: IMKB Örneği” adlı doktora tezinden türetilmiştir.

* Giresun Üniversitesi, Sosyal Bilimler Meslek Yüksekokulu, mehmet.durgut@giresun.edu.tr

** Karedeniz Teknik Üniversitesi, İktisadi ve İdari Bilimler Fakültesi, ukaya@ktu.edu.tr
} 


\section{GİRIŞ}

Muhasebe standartları şeffaf, ihtiyaca uygun, karşılaştırılabilir gibi niteliklere sahip finansal tablolar hazırlama amacıyla çıkarılmıştır. Bu çerçevede finansal tablolara konu olan tüm işlemlere yönelik birçok ilke ve kural oluşturulmuştur. Söz konusu ilke ve kurallar sadece ulusal nitelikli olmayıp uluslararası uygulamalarla da paralellik arz etmektedir. Nitekim bu çalışmada yukarıda söz konusu standartlardan bir tanesi olan TMS 19: Çalışanlara Sağlanan Faydalar standardında yer alan ve Türkiye için yeni uygulamalar içeren hükümlerden bazıları ele alınmıştır. Zira söz konusu Standart, kapsam itibariyle kısa vadeli faydalar, işten ayrılma sonrası sağlanacak faydalar, diğer uzun vadeli faydalar ve işten çıkarma tazminatları olmak üzere dört faydaya yönelik geniş kapsamlı hükümler içermektedir. Nitekim bu hükümlerin tamamının bir çalışmada ele alınması mümkün olamayacağından, bu çalışmada sadece işten ayrılma sonrası sağlanacak faydalardan "tanımlanmış fayda planları" bölümüyle ilgili hükümler ele alınmıştır. Söz konusu bölümün konusu olan tanımlanmış fayda planları, belirli bir plan dahilinde bizzat işletme tarafından ödenmesi taahhüt edilen faydaları kapsamaktadır. Çalışmamızda bu konunun tercih edilmesinin nedeni ise söz konusu uygulamanın Türkiye'de sadece kıdem tazminatı olarak biliniyor olması, diğer uygulamaların ise Türkiye için yeni olması nedeniyle literatürde yeterince incelenmemiş olmasıdır.

Yukarıda belirtilen amaç çerçevesinde hazırlanan bu çalışmanın bundan sonraki bölümlerinde ilk olarak, tanımlanmış fayda planıyla ilgili TMS 19'daki düzenlemeler üzerinde durulmuş, daha sonra ise fayda planları çerçevesinde oluşacak fayda borcunun veya varlığının yeni değerleme ölçeklerini kullanarak nasıl hesaplanacağı ve devamında da mevcut hesap planı ve önerilen yeni hesaplar çerçevesinde nasıl muhasebeleştirilebileceğine yönelik önerilerde bulunulmuştur.

\section{TANIMLANMIŞ FAYDA PLANLARININ TANIMI VE KAPSAMI}

Tanımlamış fayda planı, emeklilik döneminde çalışanlara ödenecek faydaların hesaplanmasında, genellikle çalı̧̧anların aktif çalışma süresi ile kazancının (özellikle son kazancı veya son birkaç yıldaki ortalama kazancı) esas alındığı yararlar bütünüdür (Elliott ve Elliott, 2007: 341; Lind, 2006: 5). Tanımlanmış fayda planları kapsamında çalışanın aktif çalışma hayatı boyunca aldığı maaşlardan yapılan düzenli kesintiler karşılığında emeklilik döneminde kendisine yaşam süresince belirli bir maaş ödenmektedir. Faydaya hak kazanabilmek için asgari hizmet süresinin geçerli olduğu bu tür planlarda ödenecek emekli maaşı genellikle çalışanın hizmet yılı ile son yıl veya son birkaç yıldaki ortalama kazancı esas alınarak belirlenmektedir (Zelinksy, 2009: 6).

Genellikle emekli maaşı şeklindeki faydaları kapsayan tanımlanmış fayda planlarında, çalışanlara emeklilik döneminde belirli bir ödeme yapılması garanti edilmektedir (Lacomba ve Lagos, 
2009: 2). Bu nedenle, söz konusu planlarda işletme, taahhüt edilen faydaları çalışanlara ödemek zorunda olduğundan, yükümlülükle ilgili aktüeryal risk ${ }^{2}$ ile yatırım riskini kendisi üstlenmektedir.

Tanımlanmış fayda planlarında, gelecekteki yükümlülüklerin karşılanması amacıyla işveren tarafından başka bir işletmeye (fona) varlık devri mümkündür. Böylece, işletme tarafından gerçekleştirilen bu uygulama kapsamında fona devredilen varlıkların işletmenin yükümlülüğünü karşılama derecesine bağlı olarak aşağıda ifade edilen eksik, aşırı ve tam fonlama olmak üzere üç farklı durumla karşılaşılabilmektedir (Derelioğlu, 2001: 24):

- Eksik fonlama: Fona devredilen varlıkların değerinin, işletmenin emeklilik yükümlülüğünün bugünkü değerinin altında olmasıdır. Bu durumda işletme aradaki açığı kapatmak için, fona yapılacak katkıları artırma, fonun büyümesi amacıyla katkıları yatırıma yönlendirme, açığı kendisi finanse etme gibi farklı stratejiler izleyecektir.

- Aşırı fonlama: Fona devredilen varlıkların değerinin, işletmenin emeklilik yükümlülüğünün bugünkü değerinin üzerinde olmasıdır. Böyle bir durumda fon fazlalı̆̆ı eriyinceye kadar işletmenin prim ödemeyi durdurması söz konusu olabileceği gibi aradaki fazlalığın çalışanların maaşına eklenmesi, çalışan ile işletme arasında paylaşılması veya işletme tarafından kullanılması da mümkündür.

- Tam fonlama: Fona devredilen varlıkların değerinin, işletmenin emeklilik yükümlülüğünün bugünkü değerine eşit olmasıdır.

Yukarıdaki gibi değişik fonlama çeşitlerinin olabildiği tanımlanmış fayda planları, işletmenin yükümlülüğünü karşılamak için katkıda bulunduğu fonlar üzerinde gelecekte meydana gelme ihtimali bulunan olayların etkilerinin belirlenmesi amacıyla aktüerler tarafından düzenli (genellikle 3 yılda bir) aktüeryal değerlemeye ihtiyaç duymaktadır (Rodgers, 2007: 173). Aktüerler gelecekte ödenecek yükümlülüklerin miktarını belirlemek için, plan fayda formülünün yanı sıra, ölüm oranı, personel devir hızı, emeklilik verileri, çalışanın maaşındaki artış oranı, çalışanların ortalama hizmet süresi, sermaye piyasalarının performansı, enflasyon ve faiz oranı gibi verileri kullanmaktadır (Van Greuning, 2009: 226).

Sahip olduğu özellikler çerçevesinde ana hatlarıyla yukarıda ifade edilen tanımlanmış fayda planlarında, daha uzun vadeli yatırım yapılarak daha yüksek risk alınması ve böylece daha yüksek varlık getirisi sağlanması mümkündür (Akpınar, 2007: 20). Ancak bu tür planlarda, işletmenin çalışanlara yönelik gelecekte ödeyeceği emekli maaşı şeklindeki faydalar nedeniyle üstleneceği yükümlülük, birçok değişkenden (iskonto oranı, maaş artış oranı vb.) etkileneceğinden planların işletmeye maliyeti kesin olarak belirlenememektedir (Elliott ve Elliott, 2007: 341).

\footnotetext{
${ }^{2}$ Faydaların beklenen tutardan daha düşük düzeyde gerçekleşmesidir (Rodgers, 2007: 173).
} 


\section{TANIMLANMIŞ FAYDA PLANLARININ ÖLÇÜM VE MUHASEBELEŞTİRME ILLKELERI}

Tanımlanmış fayda planlarında, işletmenin yükümlülüğü çalışanlara gelecekte ödenecek olan faydaların bugünkü değerine göre hesaplandığından bu tür planların kayda alınması özellik arz etmektedir (Van Greuning, 2009: 225). Zira tanımlanmış fayda planıyla ilgili yükümlülükler genellikle çalışanın hizmetinden çok sonra yerine getirildiğinden iskonto edilerek ölçülmekte ve yapılacak ölçümde aktüeryal varsayımlar kullanılmaktadır (TMS 19, Paragraf 48). Bu durum, tanımlanmış fayda planlarının muhasebeleştirilmesini karmaşık hale getireceğinden, işletmeler karmaşıklığın etkisini azaltmak için muhasebe sisteminde basitleştirilmiş varsayımlar ve yöntemler kullanarak gelecekteki yükümlülüklerini tahmin etmeye çalışacaktır (Amen, 2007: 251). Bu bağlamda işletmelerin, tanımlanmış fayda planı kapsamındaki yükümlülüklerini ölçebilmek için uygulamak zorunda olduğu işlemler aşağıdaki gibi olacaktır (TMS 19, Paragraf 50);

- Aktüeryal işlemlerin yapılması,

- Sağlanacak faydaların iskonto edilmesi,

- Plan varlıklarının ${ }^{3}$ gerçeğe uygun değerinin belirlenmesi,

- Aktüeryal kazanç ve kayıpların belirlenmesi,

- Planla ilgili değişiklik olması halinde ortaya çıkan geçmiş hizmet maliyetlerinin belirlenmesi,

- Planın sona ermesi veya kapsamının daraltılması halinde ortaya çıkan kazanç veya zararları belirlenmesidir.

Ölçümlenmesinde, işletmenin belirli bir işlem sırasına uymak zorunda olduğu tanımlamış fayda planlarının bilanço ve gelir tablosunda gösterimi gibi iki farklı özelliği vardır. Söz konusu özelliğe bağlı olarak TMS 19'da yer alan düzenlemeler çerçevesinde tanımlanmış fayda planı kapsamında finansal tablolarda raporlanacak unsurlar Tablo 1'deki gibi gruplandırılabilir.

\footnotetext{
${ }^{3}$ Plan Varlıkları: Uzun vadeli emeklilik fonları tarafindan elde tutulan varlıklardır (Gençoğlu, 2007: 292).
} 
Tablo 1. Tanımlanmış Fayda Planı Kapsamında Raporlanacak Unsurlar

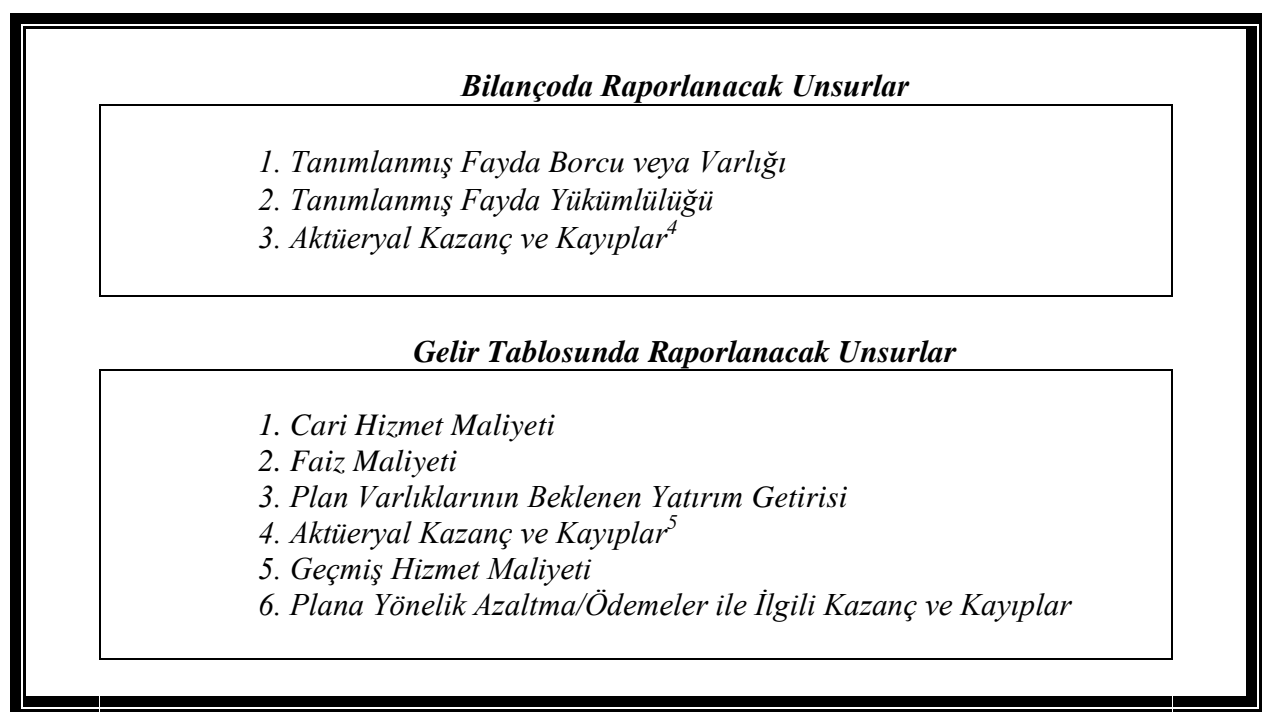

Esas itibariyle TMS 19, tanımlanmış fayda planlarının bilançoda raporlanmasını öngörmüş ve bunlarla ilgili yükümlülüklerin nasıl oluşturulacağını açıklamıştır. Fayda planlarının gelir tablosuna yansımasının ise bilançoda yer alan tanımlanmış fayda planları kapsamındaki yükümlülüklerin hareketine bağlı olarak gerçekleşeceğini ifade etmiştir (Elliott ve Elliott, 2007: 345). Nitekim tanımlanmış fayda planı kapsamındaki işlemlerin karmaşıklığı muhasebeleştirme sırasında bilanço ve gelir tablosunu ilgilendiren unsurların daha ayrıntı1ı incelenmesini gerektirmektedir. $\mathrm{Bu}$ nedenle, bu kısımda ilk olarak TMS 19'a göre tanımlanmış fayda planı kapsamında bilançoda raporlanacak unsurlar, daha sonra ise gelir tablosunda raporlanacak unsurlar üzerinde durulacaktır.

\subsection{Tanımlanmış Fayda Planı Kapsamında Bilançoda Raporlanacak Unsurlar}

Çalışma dönemi sonrasında çalışanlara sağlanacak faydaların kayda alınmasına yönelik en önemli konu, plan kapsamında ortaya çıkan borcun hesaplanması ve muhasebeleştirilme ilkelerinin belirlenmesidir. Belirtilen amaca ulaşmak için yapılacak işlemler bir sıra halinde gerçekleştirileceğinden öncelikle çalışanlara sağlanan faydalar nedeniyle ortaya çıkacak borcun hesaplanması gerekecektir.

Tanımlanmış fayda planları kapsamında bilançoya aktarılacak borç tutarı, tanımlanmış fayda planının bugünkü değeri esas alınarak belirlenir. Buna göre bilançoya aktarılacak borç tutarı aşağıdaki formül çerçevesinde hesaplanacaktır.

Tanımlanmış Fayda Borcu ${ }^{6}$ = [Tanımlanmış Fayda Yükümlülüğ̈nün Bugünkü Değeri] + [Muhasebeleş̧irilmeyen Aktüeryal Kazançlar $\left.{ }^{7}\right]$ - [Muhasebeleştirilmeyen Geçmiş Hizmet Maliyetleri] - [Plan Varlıklarının Raporlama Dönemi Sonundaki Gerçeğe Uygun Değeri]

${ }^{4}$ İsletmenin, aktüeryal kazanç ve kayıpların bilançoda kayda alınmasına yönelik bir muhasebe politikası uygulaması durumunda söz konusu olur.

5 İşletmenin, aktüeryal kazanç ve kayıpların gelir tablosunda kayda alınmasına yönelik bir muhasebe politikası uygulaması durumunda söz konusu olur. 
Tanımlanmış fayda borcunun belirlenmesinde esas alınan unsurlar ve bunlara yönelik açıklamalar aşağıdadır.

\subsubsection{Tanımlanmış Fayda Yükümlülüğünün Bugünkü Değeri}

Tanımlanmış fayda yükümlülüğünün bugünkü değeri, cari ve önceki y1llarda çalışanların sunduğu hizmetlere karşılık işletme tarafından gelecekte ödenmesi beklenen yükümlülügün belirli bir iskonto oranı üzerinden günümüze indirgenmiş değeridir. Söz konusu değerin belirlenmesinde plan varlıklarının gerçeğe uygun değerinin düşülmediği brüt yükümlülük tutarı esas alınmaktadır (TMS 19, Paragraf 7 ve 55).

Tanımlanmış fayda planı kapsamında işletmenin yükümlülüğünün belirlenmesinde TMS 19 ve Genel Kabul Görmüş Muhasebe İlkeleri (Generally Accepted Accounting Principles - GAAP) tarafından benimsenmiş olması nedeniyle tahmini fayda yükümlülüğü esas alınmaktadır (Belkaoui, 1998: 99). Tahmini fayda yükümlülüğü ise gelecekteki maaş artışları dikkate alınarak belirlenen emeklilik faydalarının bugünkü değeri olarak ifade edilmektedir (Van Greuning, 2009: 226). Fayda yükümlülügünün belirlenmesinde birçok faktör (gelecekte çalışana ödenecek son maaş, işten ayrılma ve ölüm oranları vb.) etkili olduğundan fayda planının işletmeye maliyeti açısından bir belirsizlik söz konusudur. Bu nedenle işletmenin gelecekteki fayda yükümlülüğünün bugünkü değerini ölçebilmek için aşağıda belirtilen işlemleri ${ }^{8}$ yapması gerekmektedir (TMS 19, Paragraf 63):

- Aktüeryal varsayımlar yapılması,

- Aktüeryal değerleme yönteminin uygulanması,

- Faydanın hizmet dönemine bağlanmasıdır.

Aktüeryal Varsayımlar: İşten ayrılma sonrası sağlanacak faydaların nihai maliyetinin belirlenmesinde dikkate alınan değişkenlere yönelik tahminlerdir (TMS 19, Paragraf 73). Bu varsayımlar; tanımlanmış fayda yükümlülüklerinin ölçümü, plan masraflarının belirlenmesi ve gelecekteki plan yükümlülüklerinin tahmininde kullanılan hesaplamaları içermektedir (Çakıroğlu, 2006: 26).

Aktüeryal varsayımları, demografik ve finansal varsayımlar şeklinde gruplandırmak mümkündür (Çakıroğlu, 2006: 26). Demografik varsayımlar, faydaya hak kazanabilecek mevcut ve eski çalışanlar ile onlara ekonomik olarak bağlı olanların gelecekteki özellikleriyle ilgili tahminlerdir. Demografik varsayımlar çalışma sırasında ve sonrasında yaşanan ölümler, personel devir hızı, işten

\footnotetext{
6 Tanımlanmış fayda planları kapsamında bilançoya yansıtılacak tutar, çoğunlukla tanımlanmış fayda borcu şeklinde gerçekleşse de bazen tanımlanmış fayda varlığı şeklinde de olabilir. Bu durum yukarıdaki formüle göre; yapılan hesaplama sonucunun pozitif veya negatif çıkmasına bağlıdır. Formülde verilen unsurlara göre, yapılan hesaplama sonucunun pozitif olması durumunda tanımlanmış fayda borcu; negatif olması durumunda ise tanımlanmış fayda varlığı ortaya çıkmaktadır. Tanımlanmış fayda planı kapsamında genelde raporlanacak değer borç şeklinde olduğundan bundan sonraki açıklamalarda tanımlanmış fayda borcuna vurgu yapılacaktır.

Aktüeryal kayıpların olması durumunda söz konusu kayıpların negatif etkisine bağlı olarak tanımlanmış fayda borcu veya varlığı düzeltilecektir.

${ }^{8}$ Aynı uygulamalar cari hizmet maliyeti için de geçerli olduğundan söz konusu uygulamalara yönelik yapılan açıklamalar cari hizmet maliyeti ile de ilgili olacaktır.
} 
ayrılma, maluliyet ve erken emeklilik oranları gibi konuları kapsamaktadır (FEE, 2001: 12; TMS 19, Paragraf 73). Bu tür varsayımların en önemli özelliği, çalışanlara gelecekte sağlanacak faydaların ödenme zamanının belirlenmesinde dikkate alınmasıdır (Çakıroğlu, 2006: 26). Finansal varsayımlar ise yükümlülügün gerçekleşeceği döneme ilişkin, raporlama dönemi sonundaki piyasa beklentilerine dayanan tahminlerdir. Bu varsayımlar iskonto oranı, gelecekteki maaş ve fayda düzeyleri, plan varlıklarının beklenen yatırım getirisi ve sağlık maliyetlerini kapsamaktadır (FEE, 2001: 12; TMS 19, Paragraf 73 ve 77). Finansal varsayımların çalışanlara ödenecek olan fayda tutarının belirlenmesi konusundaki gerekliliği aktüeryal varsayımlar içinde ayrı bir öneme sahip olmasını sağlamıştır (Çakıroğlu, 2006: 26).

Finansal varsayımları oluşturan unsurlardan hangilerinin değerlendirmede kullanılacağı, sağlanacak faydaların türüne, ülkeyi ve çalışanı etkileyen ekonomik faktörlere ve aktüerin hesaplama yaparken uymak zorunda olduğu kısıtlamalara bağlıdır (Çakıroğlu, 2006: 26). Nitekim aktüerler tarafindan kullanılan finansal varsayımlarda daha çok iskonto oranı, maaş artış oranı ve plan varlıklarının beklenen getiri oranı gibi unsurlar dikkate alınır. Finansal varsayımlar içinde sağlık maliyetlerinin ihmal edilmesi, bu tür faydaların ancak büyük tutarlarda olması durumunda dikkate alınmasından kaynaklanır.

Aktüeryal Değerleme Yönteminin Uygulanması: Aktüeryal değerleme, bir emeklilik planına yönelik olarak değerleme günü itibariyle, aktüeryal yükümlülüğün ve plan varlıklarının aktüeryal değerinin tespit edilme işlemidir (Şirin, 2005: 12). Temel amacı emeklilik planının yıllık maliyetinin belirlenmesi olan aktüeryal değerleme, aktüeryal yöntemler ile gerçekleştirilmektedir. İşletmeler, tanımlanmış fayda yükümlülüğünün bugünkü değerinin belirlenmesinde öngörülen yükümlüllük yöntemi olarak ifade edilen bir aktüeryal değerleme yöntemi kullanmaktadır. Öngörülen yükümlülük yöntemi, önceden belirlenmiş hizmete dayalı ya da hizmete eşit olarak bölüştürülmüş fayda yöntemi veya hizmet yılına/faydasına dayalı yöntem olarak da bilinmektedir (TMS 19, Paragraf 64). Türkiye'deki aktüeryal hesaplamalarda ise bu Yöntem daha çok öngörülen birim kredi yöntemi adı altında uygulama alanı bulmaktadır (Şahin, 2010: 11).

Öngörülen yükümlülük yöntemi, işletmenin plan kapsamında çalışanlarına gelecekte sağlayacağı faydanın cari dönemle (cari hizmet maliyetini belirlemek için) ve cari dönemi de kapsayan önceki dönemlerle (tanımlanmış fayda yükümlülüklerinin bugünkü değerini belirleyebilmek için) ilişkilendirilmesinde kullanılmaktadır (TMS 19, Paragraf 68). Nitekim söz konusu yöntem, her bir hizmet dönemini bir birim daha fayda hakkına sebep olan unsurlar olarak görmekte ve nihai yükümlülüğü oluşturmak için her birimi ayrı ayrı ölçmektedir.

Yukarıdaki ifadelerden de anlaşıldığı üzere, tanımlanmış fayda planı kapsamında öngörülen yükümlülük yöntemi, hem çalışanın her bir hizmet yılına ait fayda yükümlülüğünün bugünkü 
değerinin belirlenmesine hem de söz konusu yıllardaki fayda yükümlülüğünü oluşturan cari hizmet maliyeti, faiz maliyeti gibi unsurların ayrı ayrı hesaplanmasına imkân vermektedir.

Faydanın Hizmet Dönemine Bağlanması: Faydanın hizmet süresine bağlanması, işletme tarafından çalışanlara emeklilik döneminde sağlanacak ve en son maaşın belli bir yüzdesine göre belirlenen faydanın, çalışanın hizmet yılına bağlı olarak işletmede çalıştı̆̆ olarak dağıtılması esasına dayanmaktadır. Bu şekil bir uygulamanın amacı tanımlanmış fayda yükümlülüğü ile çalışanın aktif çalışma süresi boyunca her bir hizmet yılına ait cari hizmet maliyetinin bugünkü değerinin belirlenebilmesidir.

\subsubsection{Muhasebeleştirilmemiş Aktüeryal Kazanç ve Kayıplar}

Genel anlamda aktüeryal kazanç ve kayıplar, aktüerler tarafından kullanılan varsayımlarda meydana gelen beklenmedik değişimler sonucu ortaya çıkan değer hareketleridir (Rodgers, 2007: 175). Aktüeryal varsayımlar ile gerçekleşen durum arasındaki farklılıkları gösteren aktüeryal kazanç ve kayıplar (Şirin, 2005: 13), tanımlanmış faya planı kapsamında, ya tanımlanmış fayda yükümlülüğünün bugünkü değerinde ya da plan varlıklarının gerçeğe uygun değerinde meydana gelen değişikliklerden kaynaklanmaktadır. Bu duruma neden olan unsurları aşağıdaki gibi örneklendirmek mümkündür (TMS 19, Paragraf 94):

- Personel devir hızının beklenmedik derecede düşük ya da yüksek olması,

- İskonto oranındaki değişimlerin etkisi,

- Ölüm oranı gibi demografik tahminlerdeki değişimlerin etkisi,

- Maaş, sosyal yardım veya tıbbi maliyet artışlarındaki değişikliklerin etkisi,

- Plan varlıklarının gerçek getirisi ile beklenen getirisi arasındaki farklılıklardır.

TMS 19'un 2004'te yeniden gözden geçirilmesinden sonra, aktüeryal kazanç ve kayıpların kayda alınmasına yönelik iki alternatif yaklaşım geliştirilmiştir. Bunlardan birincisi sermaye yaklaşımı, diğeri ise aktüeryal hesaplama marjını ifade etmek üzere kullanılan koridor yaklaşımıdır (Elliott ve Elliott, 2007: 347).

a. Sermaye Yaklaşımı: Aktüeryal kazanç ve kayıpların tamamını doğrudan doğruya özkaynaklar hesap sınıfında diğer kapsamlı gelir içinde muhasebeleştirilmesini benimseyen yaklaşımdır (Elliott ve Elliott, 2007: 347).

Sermaye yaklaşımında tüm aktüeryal kazanç ve kayıplar muhasebeleştirildiğinden muhasebeleştirilmemiş aktüeryal kazanç ve kayıplar sözkonusu olmamakta, ayrıca dönemler itibariyle ortaya çıkacak söz konusu kazanç ve kayıplar birbirlerine mahsup edilebilmektedir. 
b. Koridor Yaklaşımı: Aktüeryal kazanç ve kayıplar şeklinde ortaya çıkan dalgalanmaların normal olarak kabul edilen sınırlardan büyük olmadığı sürece hemen muhasebeleştirilmesini öngörmeyen yaklaşımdır. Buna göre; aktüeryal kazanç ve kayıplar, tanımlanmış fayda yükümlülüğünün bugünkü değeri ile plan varlıklarının gerçeğe uygun değerinden daha büyük olanının \%10'undan küçük ise oluşan fark cari dönemde hemen muhasebeleştirilmeyecektir (Epstein ve Mirza, 2005: 539-540). Zira bu durum \%10 koridoru içindeki aktüeryal dalgalanmaların normal kabul edilen sınırlar içinde olmasından kaynaklanmaktadır.

\subsubsection{Muhasebeleştirilmemiş Geçmiş Hizmet Maliyeti}

Geçmiş hizmet maliyeti, geçmiş dönemlere ilişkin hizmetlere ait olmak kaydıyla, planın başlaması veya plandaki yükümlülüğün değişmesi suretiyle doğan faydaların başlama veya değişikliğin meydana geldiği tarihteki bugünkü değeridir (Arslan, 2012: 129). Bu maliyet, esas itibariyle gelir tablosunu ilgilendiren bir unsur olup bilançoyu ilgilendiren yönü yalnızca henüz muhasebeleştirilmemiş kısmının tanımlanmış fayda yükümlülüğünün hesaplanmasında dikkate alınmasıdır. Bu nedenle konuya yönelik ayrıntılı açıklamalar tanımlanmış fayda planı kapsamında gelir tablosunda raporlanacak unsurlar başlığı altında yapılacaktır.

\subsubsection{Plan Varlıklarının Gerçeğe Uygun Değeri}

Genel olarak emeklilik fon yatırımları şeklinde ifade edilen plan varlıkları, özellikli sigorta poliçeleri ile uzun vadeli emeklilik fonları tarafindan elde tutulan varlıkları kapsamaktadır. Özellikli sigorta poliçeleri raporlayan işletmenin ilişkili tarafı niteliğinde olmayan bir sigorta şirketince ihraç edilen ve gelirleri yalnızca tanımlanmış fayda planlarına ilişkin olarak çalışanlara sağlanan faydaların ödenmesinde ya da fonlanmasında kullanılabilen sigorta poliçeleridir. Uzun vadeli emeklilik fonlart tarafindan elde tutulan varlıklar ise raporlayan işletmenin ihraç ettiği devredilemez finansal araçlar dışında kalan aşağıdaki varlıklardan oluşmaktadır (TMS 19, Paragraf 7). Bunlar;

- Raporlayan işletmeden yasal olarak ayrı ve sadece çalışanlara sağlanan faydaları ödemek için kurulmuş bir fon tarafindan elde tutulan varlıklar,

- Yalnızca çalışanlara sağlanan faydaların ödenmesinde kullanılan ve raporlayan işletmeye geri dönmesi mümkün olmayan varlıklardır.

Genel hatlarıyla yukarıda ifade edilen plan varlıklarının, tanımlanmış fayda yükümlülüğünün hesaplanmasında dikkate alınabilmesi için, öncelikle gerçeğe uygun değeri belirlenmelidir. Plan varlıklarının gerçeğe uygun değeri genellikle plan varlıklarının piyasa değeridir. Piyasa değerinin tespitinin mümkün olmadığı durumlarda ise söz konusu değerin tahmin edilmesi gerekmektedir (Elliott ve Elliott, 2007: 347). 


\subsection{Tanımlanmış Fayda Planı Kapsamında Gelir Tablosunda Raporlanacak Unsurlar}

Çalışma dönemi sonrasında çalışanlara sağlanacak faydaların kayda alınmasına yönelik ikinci önemli husus söz konusu faydalarla ilgili gelir tablosunu ilgilendiren unsurların belirlenmesi ve bunlarla ilgili hesaplamaların yapılmasıdır (Belkaoui, 1998: 99). Bu yüzden belirtilen amaca ulaşmak için öncelikle sağlanan faydalar nedeniyle gelir tablosunda hangi unsurların raporlanacağının belirlenmesi gerekmektedir.

TMS 19'a göre; TMS 2 Stoklar ve TMS 16 Maddi Duran Varlıklar Standardı tarafından varlığın maliyetine dâhil edilmesi gerekenler veya buna izin verilenlerin dışında kalan aşağıdaki tutarların $\boldsymbol{n} \boldsymbol{e}$ toplamının gelir tablosunda kayda alınması gerekmektedir (Elliott ve Elliott, 2007: 348):

- Cari hizmet maliyeti,

- Faiz maliyeti,

- Plan varlıklarının beklenen yatırım getirisi,

- Muhasebeleştirilmesi halinde aktüeryal kazanç ve kayıplar,

- Geçmiş hizmet maliyeti,

- Plana yönelik azaltma veya ödemeler ile ilgili kazanç ve kayıplardır.

Yukarıdaki gibi sıralanan bu unsurları, genel olarak tanımlanmış fayda planının işletmeye olan maliyeti açısından düzenli ve düzenli olmayan giderler şeklinde sınıflandırmak mümkündür. $\mathrm{Bu}$ yaklaşıma göre cari hizmet maliyeti, faiz maliyeti, plan varlıklarının beklenen getirisi ile aktüeryal kazanç ve kayıplar düzenli giderler içinde değerlendirilirken; geçmiş hizmet maliyeti ile plana yönelik ilavelerin ya da eksiltmelerin etkisi düzenli olmayan giderler ${ }^{9}$ olarak değerlendirilir (Lewis ve Pendrill, 2004: 263). Gerek düzenli gerekse düzenli olmayan giderler içinde değerlendirilen söz konusu unsurlar aşağıda kısaca açıklanacaktır.

\subsubsection{Cari Hizmet Maliyeti}

Cari hizmet maliyeti, cari dönemde çalışanın sunduğu hizmet karş1lığında tanımlanmış fayda yükümlülüğünün bugünkü değerinde meydana gelen artıştır (Holt, 2007: 58).

Cari hizmet maliyeti, çalışanın bir dönem boyunca yerine getirdiği hizmetlere karşılık emeklilik fayda formülü ile hesaplanan faydaların aktüeryal bugünkü değeri esas alınarak bulunur. Bu nedenle cari hizmet maliyetindeki bir artış, çalı̧̧ma süresince yerine getirilen hizmetler için ödenecek tanımlanmış fayda yükümlülüğünde de artışa sebep olacaktır (Belkaoui, 1998: 99).

\footnotetext{
9 Bu tür giderler düzenli giderlerin aksine genellikle cari dönemde fayda planlarının önceden belirlenen esaslarında yapılan değişikliklere bağlı olarak ortaya çıkmaktadır.
} 
Tanımlanmış fayda yükümlülügünün ölçümünde olduğu gibi cari hizmet maliyetinin ölçümünde de öngörülen yükümlülük yöntemi kullanılmaktadır. Öngörülen yükümlülük yöntemi çerçevesinde, mevcut dönem içinde çalışan tarafından kazanılan gelecekteki emeklilik faydalarının bugünkü değerine eşit olan cari hizmet maliyeti, cari yıla ait fayda tutarı ile bugünkü değer faktörünün çarpımıyla bulunur (Belkaoui, 1998: 103).

\subsubsection{Faiz Maliyeti}

Faiz maliyeti, çalışanlara sağlanan faydaların ödenmesine bir dönem daha yaklaşılması nedeniyle tanımlanmış fayda yükümlülüğünün bugünkü değerinde meydana gelen artıştır (Holt, 2007: 58). Geçen dönemler sonucunda yükümlülüklerin gerçeğe uygun değerindeki artışı ölçen faiz maliyeti (Lewis ve Pendrill, 2004: 263), dönemin başında belirlenen iskonto oranıyla, anılan döneme ait tanımlanmış fayda yükümlülüğünün bugünkü değerinin çarpımıyla bulunur (Belkaoui, 1998: 104).

\subsubsection{Plan Varlıklarının Beklenen Yatırım Getirisi}

Plan varlıklarının beklenen yatırım getirisi, plan varlıklarının tahvil, bono ve diğer yatırımlarda değerlendirilmesine bağlı olarak gerçekleşmiş ve gerçekleşmemiş kazanç ve kayıpları ile bunlardan kaynaklanan diğer gelirler toplamından, plan yönetim maliyetleri ile plana ilişkin vergilerin düşülmesi sonucunda bulunan değerdir (Belkaoui, 1998: 104-106). Bu şekilde hesaplanan değer, fona fiilen ödenen katkı payları ile fondan fiilen ödenen tazminatlar sonucunda plan varlıklarının dönem boyunca içerdiği varlıkların gerçeğe uygun değerlerinde meydana gelen değişiklikleri yansıtmaktadır (TMS 19, Paragraf 106).

Plan varlıklarının beklenen yatırım getirisi, tahmini getiri oranına göre tespit edilmektedir. Tahmini getiri oranı, plan tarafından elde tutulan varlıklar üzerindeki yükümlülüklerin kalan süresi üzerinden tahmin edilen net plan masrafları hariç, hem gelir hem de gerçek değer içindeki değişimleri içeren ortalama getiri oranıdır. $\mathrm{Bu}$ oran aktüerlerden yardım alarak yöneticiler tarafindan oluşturulmaktadır (Lewis ve Pendrill, 2004: 263). Yapılan açıklamalar çerçevesinde plan varlıklarının beklenen getirisi aşağıdaki gibi formüle edilecektir (Belkaoui, 1998: 106):

Plan Varlıklarının Beklenen Getirisi = (Plan Varlıklarının Dönem Sonunda Gerçeğe Uygun Değeri) - (Plan Varlıklarının Dönem Başında Gerçeğe Uygun Değeri) - (Dönem İçinde Plana Yapılan Katkılar) + (Dönem İçinde Plandan Ödenen Faydalar)

Plan varlıklarının beklenen yatırım getirisi ile gerçekleşen yatırım getirisi arasındaki fark, aktüeryal kazanç ve kayıp olup \%10 koridor sınırıyla karşılaştırılan net tutarın belirlenmesi için tanımlanmış fayda yükümlülüğündeki aktüeryal kazanç ve kayıplara dâhil edilecektir (TMS 19, Paragraf 105). 


\subsubsection{Aktüeryal Kazanç ve Kayıplar}

Aktüeryal kazanç ve kayıpların gelir tablosunda kayda alınabilmesi için söz konusu kazanç ve kayıpların tanımlanmış fayda yükümlülüğünün bugünkü değeri ile plan varlıklarının gerçeğe uygun değerinden büyük olanının \%10'unu aşması gerekmektedir. Buna göre, işletmeler koridor yaklaşımı kapsamında, aktüeryal kazanç ve kayıpların oluştukları dönemde kayda alınmasına yönelik bir muhasebe politikası uygulaması durumunda, söz konusu tutarı gelir tablosunda kayda alacaktır (Morais, 2010: 43).

Koridor yaklaşımı kapsamında aktüeryal kazanç ve kayıplar, \%10 olarak belirlenen ve normal kabul edilen sınırı aşması durumunda sadece sınırı aşan kısım gelir tablosuna yansıtılacaktır ${ }^{10}$ (Morais, 2010: 43). Sınırı aşan aktüeryal kazanç ve kayıpların gelir tablosuna aktarılmasında ise işletme aşağıdaki yollardan herhangi birisini tercih edecektir (Örten, Kaval, Karapınar 2008: 315). Bunlar;

- Aktüeryal kazanç ve kayıpların tamamının, ortaya çıktığı dönemde kayda alınması,

- Aktüeryal kazanç ve kayıpların bir kısmının, ortaya çıktığı dönemde kayda alınmasıdır.

Aktüeryal kazanç ve kayıpların kayda alınmasına yönelik ikinci yolun tercih edilmesi durumunda, \%10 sınırını aşan kısım, çalışanların geri kalan çalışma sürelerine göre itfa edilecektir. Böylece gelir tablosuna aktarılacak aktüeryal kazanç ve kayıplar ortaya çıktığı dönemi takiben, çalışanın kalan hizmet süresi içinde sistematik olarak kayda alınacaktır (Elliott ve Elliott, 2007: 347). Belirlenen \%10 sınırının üzerindeki fazlalığın muhasebeleştirilmesinde aktüeryal kazanç ve kaybın tamamı yerine sadece bir kısmının, ortaya çıktığı dönemde kayda alınması şeklinde bir uygulama ile TMS 19'un muhasebe temel kavramlarından dönemsellik kavramına vurgu yaptığı anlaşılmaktadır.

İşletmeler, aktüeryal kazanç ve kayıplara yönelik uygulanan muhasebe politikalarının dönemler itibariyle tutarlı olması ve aynı politikaların hem kazanca hem de kayba uygulanması koşuluyla aktüeryal kazanç ve kayıplarını daha hızlı şekilde muhasebeleştirebilmek için sistematik bir takım yöntemler de kullanabilir (TMS 19, Paragraf 93). Bu durumda söz konusu yöntemler ile işletmeler ortaya çıkacak aktüeryal kazanç ve kayıpların tamamını \%10 sınırı içinde olup olmadığına bakmaksızın, gelir ya da gider şeklinde kayda alabilecektir (Elliott ve Elliott, 2007: 347).

\subsubsection{Geçmiş Hizmet Maliyeti}

Geçmiş hizmet maliyeti, ya işletmenin mevcut tanımlanmış fayda planı kapsamındaki geçmiş hizmetlerle ilgili faydalarda değişiklik yapması ya da faydaları geçmiş hizmetlerle ilişkilendiren yeni bir tanımlanmış fayda planı oluşturması durumunda ortaya çıkmaktadır. Faydalarla ilgili bu değişiklikler çalışanlar tarafından sunulacak hizmetlere karşılık yapılmaktadır. Bu nedenle, geçmiş

10 TMS 19'a göre koridor yaklaşımını uygulayan işletmeler hem aktüeryal kazançları hem de aktüeryal kayıpları gelir tablosuyla ilişkilendirmek zorundadır. 
hizmet maliyeti çalışanın önceki dönemdeki hizmetlerine ilişkin ortaya çıktığı gerçeği dikkate alınmaksızın, anılan dönemde finansal tablolara yansitılmalıdır (Gençoğlu, 2007: 295).

İşletme uygun olması durumunda, geçmiş hizmet maliyetini belirleyebilmek için de öngörülen yükümlülük yöntemini kullanacaktır (Amen, 2007: 246). Bu yöntem çerçevesinde geçmiş hizmet maliyeti, maliyette meydana gelen düzeltmeden kaynaklanan değişiklik olarak ölçülecektir. Buna göre; geçmiş hizmet maliyeti yükümlülügün ölçümünde, ilgili faydalara hak kazanılacak ortalama süreye kadar eşit tutarlarda giderleştirecektir. Fayda planında yapılan değişiklikler ile faydaya hak kazanılması durumunda ise işletme geçmiş hizmet maliyetini oluştuğu anda doğrudan gelir tablosunda muhasebeleştirecektir.

\subsubsection{Plana Yönelik Azaltma veya Ödemeler ile İlgili Kazanç ve Zararlar}

Plana yönelik azaltma veya ödemeler ile ilgili kazanç ve zararlar, plan içindeki değişikliklerle ilgili kazanç ve zararlar olarak ifade edilmektedir (Lewis ve Pendrill, 2004: 264). Azaltma veya ödemelerden kaynaklanan bu tür kazanç ve zararlar aşağıdaki işlemler sonucu ortaya çıkmaktadır (TMS 19, Paragraf 109). Bunlar;

- Tanımlanmış fayda yükümlülüğünün bugünkü değerinde meydana gelen değişiklik,

- Plan varlıklarının bugünkü değerindeki değişiklik,

- Muhasebeleştirilmemiş aktüeryal kazanç ve kayıplar ile geçmiş hizmet maliyetidir.

İşletme yukarıdaki gibi sıralanan unsurları, ilgili azaltma veya ödemeler meydana geldiğinde finansal tablolara yansıtacağından öncelikle finansal tablolara aktarılacak olan kazanç ve zararlarla ilgili azaltma veya ödeme olaylarının tespit edilmesi gerekmektedir. TMS 19 standardı çerçevesinde azaltma, plan kapsamındaki çalışanların sayısının ya da çalışanlara sağlanan fayda tutarının düşürülmesi, ödeme ise işverene ait yükümlülügün işletme tarafından tamamen ya da kısmen yerine getirilmesi şeklinde basitçe tanımlanabilir.

Tanımlanmış fayda planı kapsamında mevcut dönemde bir azaltma veya ödeme işlemine bağlı olarak bir kazanç veya zarar meydana geldiğinde bu durumun tanımlanmış fayda yükümlülüğ̈̈ ile ilişkilendirilmesi gerekmektedir. Bir başka ifadeyle işletmenin azaltma veya ödeme işlemi sonucunda bir kazancı ortaya çıktığında, söz konusu bu kazanç ilgili dönemin kârına eklenmesine karşılık bilançodaki fayda yükümlülügü tutarından düşülecektir. Zarar ortaya çıktığında ise tersi işlemler yapılacaktır.

Gelir tablosunda muhasebeleştirilecek unsurlarla ilgili yukarıda yapılan açıklamalardan da anlaşıldığı üzere TMS 19 tanımlanmış fayda planları kapsamında gelir tablosunda kayda alınacak unsurların neler olduğunu açıkça belirtmiş ve bunlara yönelik ayrıntılı açıklamalarda bulunmuştur. Buna rağmen, söz konusu unsurlardan cari hizmet maliyeti, faiz maliyeti ve plan varlıklarının 
beklenen yatırım getirisinin gelir tablosunda ayrı bir gelir ya da gider kalemi olarak gösterilip gösterilmeyeceği konusunda ise ayrıntılı bir belirlemede bulunmamıştır.

\section{TANIMLANMIŞ FAYDA PLANLARININ MUHASEBELEŞTİRILMESİ}

TMS 19 tarafından düzenlenen çalışma dönemi sonrası faydalar içinde değerlendirilen tanımlanmış fayda planları Türkiye'de yeni bir uygulama olduğundan çalışmanın bu kısmında söz konusu faydaların Türk Tekdüzen Hesap Planı (THP) içinde mevcut hesapların yanı sıra açılması önerilen bazı hesaplar ile birlikte muhasebeleştirilmesi üzerinde durulacaktır.

\subsection{Tanımlanmış Fayda Planlarının Muhasebeleştirilmesinde Kullanılacak Hesapların İncelenmesi}

Tanımlanmış fayda planlarının hem gelir tablosu ve bilançoda raporlanan unsurlar içermesi hem de planların içeriğini oluşturan unsurların çeşitliliği, yükümlülüğün belirlenmesinde değişik faktörlerin dikkate alınması, riskin azaltılması için fona varlık devrinin yapılması gibi nedenler tanımlanmış fayda planlarının raporlanmasında özellik arz eden bazı hesapların kullanılmasını gerekli kılmaktadır. Nitekim bu durum konuyla ilgili çalışmalarda çeşitli hesapların kullanılmasına zemin hazırlamıştır. Örneğin Gençoğlu (2007), tanımlanmış fayda planı kapsamındaki bir yükümlülüğün 335 Personele Borçlar Hesabı'nda, daha sonraki yıllarda giderleştirilecek emeklilik giderlerinin 280 Gelecek Yıllara Ait Giderler Hesabı'nda, fona aktarılacak varlıkların 136 Diğer Çeşitli Alacaklar Hesabı'nda, fon varlıklarının değerinde meydana gelen artışların ise 648 Borsada Değer Artış Kârları Hesabı'nda kayda alınmasını önermiştir. Belkaoui (1998) ise tanımlanmış fayda planlarının kayda alınmasında, söz konusu plan kapsamındaki unsurların niteliklerine uygun olarak Emeklilik Borçları Hesabı, Ertelenmiş Emeklilik Giderleri Hesabı, Tahakkuk Etmiş Emeklilik Giderleri Hesabı gibi farklı hesapların kullanılmasını önermiştir.

Yukarıdaki ifadelerden de anlaşıldığı üzere konuyla ilgili sınırlı sayıda çalışmanın yer aldığı muhasebe literatüründe, tanımlanmış fayda planlarının hangi hesaplarda raporlanacağına yönelik görüş birliği olmamasına rağmen; "tam açıklama” ve "özün önceliği”" kavramı gereğince plan kapsamındaki bilgilerin daha açık bir şekilde çıkar gruplarına sunulabilmesi için birden fazla hesabın kullanılması daha uygun olacaktır. Buna göre tanımlanmış fayda planlarının kayda alınmasında kullanılacak hesaplar, Akdoğan ve Sevilengül (2007) tarafından TMS'ye uyum için THP'de yapılan değişikliklere bağlı olarak oluşturulan 374/474 Çalışanlara Sağlanan Diğer Faydalar İlişkin Karşılıklar Hesabı'nın yanı sıra bu değişiklikler sonucunda şekillenen yeni THP'ye ilave edilecek 140/240 Plan Varlıklarından Alacaklar Hesabı, 184/284 Ertelenmiş Emeklilik Giderleri Hesabı gibi bazı hesapları da içerecektir. Tanımlanmış fayda planları kapsamında plan varlıklarının değerinde meydana gelen artışlar ile ilgili bilgiler ise 642 Faiz Gelirleri Hesabı altında gelir tablosunda raporlanacaktır. 
Tanımlanmış fayda planlarının gerek bilançoda gerekse de gelir tablosunda kayda alınmasında kullanılacak mevcut ve önerilen yeni hesaplar aşağıda açıklanmıştır.

140 Plan Varlıklarından Alacaklar Hesabı: Tanımlanmış fayda planı kapsamındaki yükümlülüklerin karşılanması için işveren işletme tarafindan başka bir işletmeye (fona) aktarılan varlıklar nedeniyle ortaya çıkan ve bilanço tarihi itibariyle on iki ay içinde fondan tahsil edilecek alacakların izlenildiği hesaptır.

Hesabın işleyişi: Fona yapılan katkılara bağlı olarak bilanço tarihi itibariyle on iki ay içinde fondan tahsil edilecek bir alacağın doğması durumunda bu hesaba borç; alacağın tahsil edilmesi durumunda ise bu hesaba alacak yazllır.

240 Plan Varlıklarından Alacaklar Hesabı: Tanımlanmış fayda planı kapsamındaki yükümlülüklerin karşılanması için işveren işletme tarafindan başka bir işletmeye (fona) aktarılan varlıklar nedeniyle ortaya çıkan ve on iki ay içinde tahsil edilmeyecek alacakların izlenildiği hesaptır.

Hesabın işleyişi: Fona aktarılan varlıklara bağlı olarak ortaya çıkan alacaklar ile söz konusu varlıkların gerçeğe uygun değerinde meydana gelen artışlar bu hesabın borcuna; fondan tahsil edilen tutarlar ise alacağına kaydedilir. Bilanço tarihi itibariyle on iki ay içinde fondan tahsil edilecek alacaklar bu hesaptan 140 Plan Varlıklarından Alacaklar Hesabı'na aktarllır.

184 Ertelenmiş Emeklilik Giderleri Hesabı: Tanımlanmış fayda planları kapsamında ortaya çıkan ve on iki ay içinde gider veya maliyet hesaplarına aktarllacak emeklilik giderlerinin izlenildiği hesapttr.

Hesabın işleyişi: Bilanço tarihi itibariyle on iki ay içinde gider veya maliyet hesaplarına aktarılacak emeklilik giderleri 284 Ertelenmiş Emeklilik Giderleri Hesabı'nın alacağına karşılık, bu hesaba borç kaydedilir. Emeklilik giderlerinin, gider veya üretim maliyet hesaplarına aktarlması durumunda ise bu hesaba alacak, ilgili gider veya üretim maliyeti hesabına borç yazllır.

284 Ertelenmiş Emeklilik Giderleri Hesabı: Tanımlanmış fayda planları kapsamında ortaya çıkan ve on iki ay içinde gider veya maliyet hesaplarına aktarılmayan emeklilik giderlerinin izlenildiği hesaptır.

Hesabın işleyişi: Cari dönemde ortaya çıkan ve on iki ay içinde gider veya maliyet hesaplarına aktarllmayan emeklilik giderleri 474 Çalışanlara Sağlanacak Diğer Faydalara İlişkin Karşılıklar Hesabı'nın alacağına karşılık bu hesaba borç kaydedilir. Bilanço tarihi itibariyle on iki ay içinde gider veya maliyet hesaplarına aktarlacak emeklilik giderleri ise bu hesaba alacak, 184 Ertelenmiş Emeklilik Giderleri Hesabı'na borç yazılır.

374 Çalışanlara Sağlanacak Diğer Faydalara İliş̧in Karşılıklar Hesabı: Bu hesap bilanço tarihi itibariyle on iki ay içinde ödenecek tanımlanmış fayda planı kapsamındaki yükümlülüklerin kayda alınmasinda kullanılmaktadır. 
Hesabın İşleyişi: On iki ay içinde ödenecek olan tanımlanmış fayda planı kapsamında ortaya çıkacak bir yükümlülük bu hesaba alacak; ilgili bir gider ya da üretim maliyeti hesabına borç kaydedilir. Söz konusu yükümlülüğ̈̈n ödenmesi durumunda bu hesaba borç, ilgili ödeme hesabına ise alacak kaydedilir. Ayrıca, bilanço tarihi itibariyle on iki ay içinde ödenmesi gereken faydalardan kaynaklanan yükümlülük 474 Çalışanlara Sağlanacak Diğer Faydalara İlişskin Karşılıklar Hesabı'nın borcuna karşılık bu hesabın alacağına yazılır.

474 Çalışanlara Sağlanacak Diğer Faydalara İlişsin Karşılıklar Hesabı: Tanımlanmış fayda planı kapsamında ortaya çıkan yükümlülüklerin izlenildiği hesaptır.

Hesabın işleyişi: Tanımlanmış fayda planı kapsamındaki bir yükümlülük bu hesaba alacak ilgili bir gider veya üretim maliyeti hesabına borç kaydedilir. Bilanço tarihi itibariyle ödenmesi on iki ay içinde gerçekleştirilecek olan faydalar ise bu hesaptan 374 Çalışanlara Sağlanacak Diğer Faydalara İlişkin Karşılıklar Hesabı'na aktarılır.

555 Aktüeryal Kazanç ve Kayıplar Hesabı (+ / -): Özkaynaklarda kayda alınması durumunda tanımlanmış fayda planına bağlı olarak ortaya çıkan aktüeryal kazanç ve kayıpların izlenildiği hesaptır. Gerek aktüeryal kazançların gerekse de aktüeryal kaytplartn bu hesaba kaydedilmesi nedeniyle söz konusu hesap çift yönlü çalışma özelliğine sahiptir.

Hesabın işleyişi: Tanımlanmış fayda planına bağlı olarak ortaya çıkan aktüeryal kazançlar bu hesaba alacak, kaylplar ise borç kaydedilecektir. Bu hesap 474 Çalışanlara Sağlanacak Diğer Faydalara İlişkin Karşılıklar Hesabı ile karşılıklı çalışmaktadır.

642 Faiz Gelirleri Hesabı: Plan varlıklarının değerinde meydana gelen artışların izlenildiği hesaptır.

Hesabın işleyişi: Plan varlıklarının değerinde meydana gelen artışlar bu hesabın alacağına karşılık 140/240 Plan Varlıklarından Alacaklar Hesabı'na borç kaydedilir.

\section{2. Örnek Uygulama}

Otomotiv imalatı alanında faaliyet gösteren "E" A.Ş., Ali AYDIN adındaki çalışanına aktif çalışma döneminden sonra fayda sağlamak amacıyla çalışanın emeklilik tarihinden 4 yıl önce yani 01.01.2011 tarihinde bir tanımlanmış fayda planı oluşturmuştur. Yapılan plana göre Ali AYDIN'a emeklilik tarihinde ödenecek muhtemel faydaların 4 y1l sonraki değeri 24.000,-TL'dir. Plana ilişkin diğer bilgiler ise aşağıdaki gibidir:

- Y1lık maaş, emekli oluncaya kadar yani 4 yıl boyunca değişmeyecektir.

- Tanımlanmış fayda planı kapsamında uygulanacak iskonto oranı 2011 ve 2012 yılları için \%10; 2013 ve 2014 yılları için \%8'dir.

- Plana yapılan katkılar her yılın sonunda gerçekleştirilmektedir. 
- Ali AYDIN'ın hizmet yılını tamamlayamama ihtimali son derece düşüktür.

- Aktüeryal kazanç ve kayıpların muhasebeleştirilmesinde sermaye yaklaşımı tercih edilmiş ve enflasyonun etkisi ihmal edilmiştir.

- Plan varlıklarının beklenilen getiri oranı periyodun tamamı için \%12 olup; plana yapılan katkılar ile plan varlıklarının gerçek değerinin 4 yıllık hizmet süresi içinde aşağıdaki gibi gerçekleşeceği varsayılmıştır.

\begin{tabular}{|l|c|c|}
\hline Tarih & Plana Yapılan Katkılar & $\begin{array}{c}\text { Varlıkların Gerçĕge Uygun } \\
\text { Değeri }\end{array}$ \\
\hline 31 Aralık2011 & $4.270,-T L$ & $4.270,-T L$ \\
\hline 31 Aralık2012 & $4.784,-T L$ & $9.082,-T L$ \\
\hline 31 Aralık2013 & $5.357,-T L$ & $15.739,-T L$ \\
\hline 31 Aralık2014 & $6.000,-T L$ & $23.621,-T L$ \\
\hline
\end{tabular}

Yukarıda yer alan bilgiler çerçevesinde Ali AYDIN'a ait tanımlanmış fayda planı kapsamında "E” A.Ş. tarafından bilanço ve gelir tablosuna aktarılacak unsurlar aşağıdaki işlem sırasına göre belirlenecektir. Bunlar;

- Her bir yıla ait fayda tutarının ve bugünkü değer faktörünün hesaplanması,

- Tanımlanmış fayda yükümlülüğün bugünkü değerinin hesaplanması,

- Plan varlıklarının değerinde meydana gelen değişimlerin hesaplanması,

- Gerek tanımlanmış fayda yükümlülüğünün bugünkü değerinde gerekse de plan varlıklarının gerçeğe uygun değerinde meydana gelen değişikliklerden kaynaklanan aktüeryal kazanç ve kayıpların hesaplanmas1,

- Tanımlanmış fayda borcunun hesaplanmasıdır.

\section{a. Fayda Tutarının ve Bugünkü Değer Faktörünün Hesaplanması}

Çalışan Ali AYDIN'a emekliliğinde ödenecek muhtemel faydaların toplamı 24.000,-TL olduğundan her bir yıla ait fayda tutarı 6.000,-TL (24.000,-TL/4yıl) şeklinde hesaplanırken; bugünkü değer faktörü ise, $1 /\left(1+\right.$ Ískonto Oranı) ${ }^{\text {vadeye kalan yl saysı }}$ formülüne göre iskonto oranındaki değişimleri de yansıtacak şekilde her bir yıl için aşağıdaki gibi hesaplanacaktır.

\begin{tabular}{|l|c|c|c|}
\hline Yıllar & İskonto Oranı & Vadeye Kalan Yll Sayısı & Bugünkü Değer Faktörü \\
\hline 2011 & $\% 10$ & 3 & 0,7511 \\
\hline 2012 & $\% 10$ & 2 & 0,8265 \\
\hline 2013 & $\% 8$ & 1 & 0,9258 \\
\hline 2014 & $\% 8$ & 0 & 1,0000 \\
\hline
\end{tabular}

\section{b. Tanımlanmış Fayda Yükümlülüğün Bugünkü Değerinin Hesaplanması}

Tanımlanmış fayda planı kapsamında, Ali AYDIN ile ilgili olarak yukarıda verilen bilgiler çerçevesinde tanımlanmış fayda yükümlülüğünün bugünkü değeri aşağıdaki gibi hesaplanacaktır. 


\begin{tabular}{|c|c|c|c|c|}
\hline Yıllara İlişkin Fayda ve Yükümlülük Tutarları & \multicolumn{4}{|c|}{ Yillar } \\
\hline Yıllara İlişkin Fayda Tutarları (TL) & 2011 & 2012 & 2013 & 2014 \\
\hline Cari yıla ilişkin fayda tutarı (a) & $6.000,-$ & $6.000,-$ & $6.000,-$ & $6.000,-$ \\
\hline Önceki yıllara ilişkin fayda tutarı & - & $6.000,-$ & $12.000,-$ & 18.000,- \\
\hline Cari yıl ile önceki yıllara ilişsin toplam fayda tutarı (b) & $6.000,-$ & $12.000,-$ & 18.000,- & 24.000,- \\
\hline Yıllara İlişkin Yükümlülük Tutarları (TL) & 2011 & 2012 & 2013 & 2014 \\
\hline Bugünkü değer faktörü (c) & 0,7511 & 0,8264 & 0,9258 & 1,0000 \\
\hline Ískonto (faiz) oranı (d) & $\% 10$ & $\% 10$ & $\% 8$ & $\% 8$ \\
\hline Açıllş yükümlülüğ̈ü $(e)^{l l}$ & - & 4.507,- & 9.917,- & 16.666,- \\
\hline Cari hizmet maliyeti $(f)=(a \times c)$ & 4.507,- & 4.959,- & $5.556,-$ & $6.000,-$ \\
\hline Faiz maliyeti $(g)=(e \times d)$ & - & $451,-$ & $793,-$ & $1.334,-$ \\
\hline Aktüeryal kazanç ve kayıplar (h) & - & - & $400,-$ & - \\
\hline Kapanış yükümlülüğü $(b \times c)$ veya $(e+f+g+h)$ & 4.507 & 9.917,- & 16.666,- & 24.000,- \\
\hline Yükümlülüğün bir önceki yıla göre değisşimi & 4.507,- & $5.410,-$ & 6.749,- & 7.334,- \\
\hline
\end{tabular}

Yukarıdaki hesaplamalardan da anlaşıldığı üzere 2013 yılına ait tanımlanmış fayda yükümlülügünün kapanış değerini gösteren $16.666,-T L$, açılış yükümlülüğü, cari hizmet maliyeti ve faiz maliyetinin yanı sıra 2013 yılında iskonto oranında meydana gelen değişikliğe bağlı olarak ortaya çıkacak aktüeryal kaybı da içermektedir. Zira iskonto oranındaki azalış şeklindeki bir değişiklik tanımlanmış fayda yükümlülüğ̈̈n̈̈n bugünkü değerini artıracaktır. Buna göre 2013 yılında ortaya çıkan aktüeryal kayıp, 2013 yılında tanımlanmış fayda yükümlülüğünün kapanış değerinden (16.666,TL), aynı yıla ait açı1ış yükümlülüğü $(9.917,-T L)$, cari hizmet maliyeti $(5.556,-T L)$ ve faiz maliyeti (793,-TL)'nin düşülmesi ile 400,-TL olarak hesaplanacaktır.

\section{c. Plan Varlıklarının Değerinde Meydana Gelen Değişimlerin Hesaplanması}

Tanımlanmış fayda planı kapsamında bilançoya aktarılacak net borcun hesaplanmasında tanımlanmış fayda yükümlülüğünün bugünkü değerinin yanı sıra plan varlıklarının değerindeki değişimlerin de dikkate alınması gerekmektedir. Bu bağlamda işletmenin, çalışanlarına emeklilik sonrası sağlayacağı faydaların finansmanına yönelik oluşturduğu plan varlıklarının, plana yapılan katkılar, varlıkların beklenilen ve gerçekleşen getirisi, aktüeryal kazanç ve kayıplar gibi unsurlarla birlikte yıllar itibariyle görünümü aşağıdaki gibi olacaktır.

\footnotetext{
${ }^{11}$ Açı1ış yükümlülüğü, bir önceki yılın kapanış yükümlüğüdür.
} 


\begin{tabular}{|c|c|c|c|c|}
\hline Plan Varlıklarının Getirisi & 2011 & 2012 & 2013 & 2014 \\
\hline Varlıkların dönem başındaki gerçeğe uygun değeri (a) & ------ & $4.270,-$ & 9.082,- & $15.739,-$ \\
\hline Plan varlıklarının beklenen getirisi (dönem başı varlıkların \%12'si) (b) & ------- & $512,-$ & $1.090,-$ & $1.888,-$ \\
\hline Plana yapılan katkılar (c) & $4.270,-$ & $4.784,-$ & $5.357,-$ & $6.000,-$ \\
\hline Beklenen getiri temelinde döne & $4.270,-$ & $9.566,-$ & $15.529,-$ & $23.627,-$ \\
\hline Dönem sonunda plan varlıklarının gerçeğe uygun değeri $(f)$ & $4.270,-$ & 9.082,- & $15.739,-$ & $23.621,-$ \\
\hline Plan varlıklarının değerindeki artış $(g)=[f-(a+c)]$ & $0,-$ & $28,-$ & $1.300,-$ & $1.882,-$ \\
\hline Aktüeryal kazanç ve kayıp (g-b) & ------ & $(484,-)$ & $210,-$ & $(6,-)$ \\
\hline
\end{tabular}

\section{d. Toplam Aktüeryal Kazanç ve Kayıpların Hesaplanması}

Gerek tanımlanmış fayda yükümlülüğünün bugünkü değerinde meydana gelen değişikliğe bağlı olarak gerekse plan varlıklarının beklenilen getirisi ile gerçekleşen getirisi arasındaki farklardan kaynaklanan aktüeryal kazanç ve kayıpların tanımlanmış fayda planı kapsamında birlikte değerlendirilmesi gerekmektedir. Buna göre; söz konusu kazanç ve kayıpların yıllar itibariyle net değişimi aşağıda gösterilmiştir.

\begin{tabular}{|l|r|r|r|r|}
\hline Aktüeryal Kazanç ve Kayıplar & 2011 & 2012 & 2013 & 2014 \\
\hline $\begin{array}{l}\text { Plan varlıklarının beklenen ve gerçekleşen getirisinden } \\
\text { kaynaklanan aktüeryal kazançve kayılar (TL) }\end{array}$ & ----- & $(484,-)$ & $210,-$ & $(6,-)$ \\
\hline $\begin{array}{l}\text { Fayda yükümlülüklerinden kaynaklanan aktüeryal kazanç ve } \\
\text { kayıplar (TL) }\end{array}$ & ----- & ------ & $(400,-)$ & ----- \\
\hline $\begin{array}{l}\text { Muhasebelesstirilecek toplam aktüeryal kazanç ve } \\
\text { kayıplar(TL) }\end{array}$ & ------ & $(484,-)$ & $(190,-)$ & $(6,-)$ \\
\hline
\end{tabular}

\section{e. Tanımlanmış Fayda Borcunun Hesaplanması}

Tanımlanmış fayda yükümlülüğünün bugünkü değeri ve plan varlıklarının gerçeğe uygun değerine yönelik yukarıda yapılan hesaplamalar çerçevesinde tanımlanmış fayda planı kapsamında bilançoya aktarılacak tanımlanmış fayda borcunun tutarı aşağıdaki formüle göre belirlenecektir.

Tanımlanmış Fayda Borcu $=$ (Tanımlanmış Fayda Yükümlülüğ̈̈nün Bugünkü Değeri) + (Muhasebeleştirilmeyen Aktüeryal Kazançlar) - (Muhasebeleştirilmeyen Geçmiş Hizmet Maliyetleri) - (Plan Varlıklarının Raporlama Dönemi Sonundaki Gerçeğe Uygun Değeri)

Tanımlanmış fayda borcunun hesaplanmasında kullanılan formüle göre bilançoya aktarılacak tanımlanmış fayda borcunun yıllar itibariyle görünümü aşağıdaki gibi olacaktır.

\begin{tabular}{|l|c|c|c|c|}
\hline 31 Aralık Bilançosu & $\mathbf{2 0 1 1}$ & $\mathbf{2 0 1 2}$ & $\mathbf{2 0 1 3}$ & $\mathbf{2 0 1 4}$ \\
\hline Fayda yükümlülüğ̈̈̈nün bugünkü değeri (TL) (a) & $4.507,-$ & $9.917,-$ & $16.666,-$ & $24.000,-$ \\
\hline Plan varlıklarının gerçeğe uygun değeri (TL) (b) & $4.270,-$ & $9.082,-$ & $15.739,-$ & $23.621,-$ \\
\hline Tanımlanmış fayda borcu (net yükümlüliük) (TL) (a-b) & $\mathbf{2 3 7 , -}$ & $\mathbf{8 3 5 , -}$ & $\mathbf{9 2 7 , -}$ & $\mathbf{3 7 9 , -}$ \\
\hline Önceki yıla göre değğişim (TL) & $\mathbf{2 3 7 , -}$ & $\mathbf{5 9 8 , -}$ & $\mathbf{3 2 9 , -}$ & $\mathbf{( 5 4 8 , - )}$ \\
\hline
\end{tabular}

Tanımlanmış fayda planıyla ilgili olarak bilançoya yansıtılacak net borç tutarının yanı sıra gelir tablosuna aktarılacak unsurlar ve tutarlarının da belirlenmesi gerekmektedir. TMS 19'da yer alan düzenlemeler çerçevesinde gelir tablosuna aktarılacak tutar; cari hizmet maliyeti, faiz maliyeti, plan varlıklarının beklenilen yatırım getirisi gibi unsurların net toplamına göre belirlenmektedir. $\mathrm{Bu}$

\footnotetext{
${ }^{12}$ İşletme, sermaye yaklaşımını benimsemesi nedeniyle, oluşan kayıp ve kazançların tamamını muhasebe kayıtlarına aktaracaktır.
} 
bağlamda, Ali AYDIN'a ait tanımlanmış fayda planı çerçevesinde gelir tablosuna aktarılacak unsurlar ve tutarları aşağıda gösterilmiştir.

\begin{tabular}{|c|c|c|c|c|}
\hline 31 Aralık Gelir Tablosu & 2011 & 2012 & 2013 & 2014 \\
\hline $\operatorname{Giderler}(T L)$ & $(4.507,-)$ & $(5.410,-)$ & $(6.349,-)$ & $(7.334,-)$ \\
\hline - Cari hizmet maliyeti (TL) & $(4.507,-)$ & $(4.959,-)$ & $(5.556,-)$ & $(6.000,-)$ \\
\hline -Faiz maliyeti $(T L)$ & ------- & $(451,-)$ & $(793,-)$ & $(1.334,-)$ \\
\hline $\operatorname{Gelirler}(T L)$ & & $512,-$ & $1.090,-$ & $1.888,-$ \\
\hline -Plan varliklarının beklenilen getirisi (TL) & ------ & $512,-$ & $1.090,-$ & $1.888,-$ \\
\hline Net Tutar (TL) & $(4.507,-)$ & $(4.898,-)$ & $(5.259,-)$ & $(5.446,-)$ \\
\hline
\end{tabular}

Çalışan Ali AYDIN'a aktif çalışma dönemi sonunda ödenecek tanımlanmış fayda planı kapsamında finansal tablolara aktarılacak unsurlara yönelik yukarıda yapılan hesaplamaları aşağıdaki gibi özetlemek mümkündür.

\begin{tabular}{|c|c|c|c|c|}
\hline Tanımlanmış Fayda Planının Unsurları & 2011 & 2012 & 2013 & 2014 \\
\hline \multicolumn{5}{|l|}{ Bilançoda Raporlanacak Unsurlar } \\
\hline Tanımlanmış fayda yükümlülüğünün bugünkü değeri (TL) & $4.507,-$ & $5.410,-$ & $6.749,-$ & $7.334,-$ \\
\hline Tanımlanmış fayda borcu (TL) & $237,-$ & $598,-$ & $329,-$ & $(548,-)$ \\
\hline Aktüeryal kazanç ve kayıplar (TL) & ------ & $(484,-)$ & $(190,-)$ & $(6,-)$ \\
\hline \multicolumn{5}{|l|}{ Gelir Tablosunda Raporlanacak Unsurlar } \\
\hline Cari hizmet maliyeti $(T L)(a)$ & $(4.507,-)$ & $(4.959,-)$ & $(5.556,-)$ & $(6.000,-)$ \\
\hline Faiz maliyeti $(T L)(b)$ & $\begin{array}{ll}--\cdot--- \\
\end{array}$ & $(451)-$, & $(793)-$, & $(1.334,-)$ \\
\hline Plan varliklarının beklenilen getirisi (TL) (c) & $\begin{array}{ll}--\cdot--- \\
\end{array}$ & $512,-$ & $1.090,-$ & $1.888,-$ \\
\hline Toplam Dönem Gideri $(T L)(a+b-c)$ & $(4.507,-)$ & $(4.898,-)$ & $(5.259,-)$ & $(5.446,-)$ \\
\hline
\end{tabular}

Çalışan Ali AYDIN'a ait tanımlanmış fayda planı kapsamında "E” A.Ş.'nin, yukarıdaki gibi özetlenen ve muhasebeleştirmede esas alacağı, gerek bilanço gerekse gelir tablosunda raporlayacağı unsurlara ilişkin kayıtları yıllar itibariyle aşağıdaki gibi olacaktır.

\section{a. 2011 yılı için yapılacak kayıtlar}

2011 yılına ait tanımlanmış fayda yükümlülüğünün ve dönem giderinin kaydı aşağıdaki gibi olacaktır.

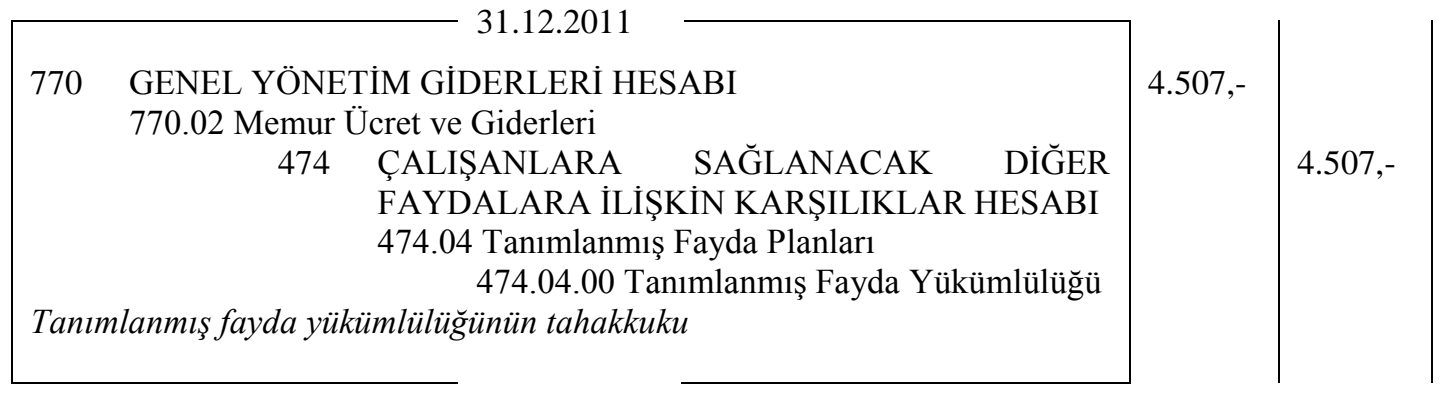

2011 yılında tanımlanmış fayda planı kapsamında gelir tablosuna aktarılacak gider tutarı, faiz maliyeti ve aktüeryal kazanç ve kayıp olmadığından, yalnızca cari hizmet maliyetinden oluşacaktır.

"E” A.Ş.'in dönem sonunda plana yaptığı katkıların kaydı aşağıdaki gibi olacaktır. 


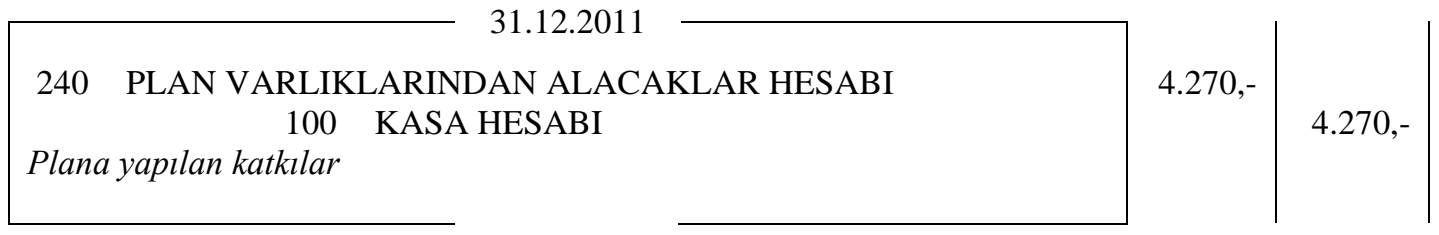

"E” A.Ş. tarafından 2011 yılında tanımlanmış fayda planı kapsamında bilançoya aktarılacak tanımlanmış fayda borcu niteliğindeki ilave yükümlülük tutarının da dikkate alınması gerekmektedir. Buna göre tanımlanmış fayda borcu aşağıdaki gibi kayda alınacaktır.

31.12.2011

284 ERTELENMIȘ EMEKLILIIK GIDERLERİ HESABI

474 ÇALIŞANLARA SAĞLANACAK DİĞER

FAYDALARA İLIŞKIN KARŞILIKLAR HESABI

474.04 Tanımlanmış Fayda Planları

474.04.01 Tanımlanmıș Fayda Borcu

Tanımlanmış fayda borcunun tahakkuku

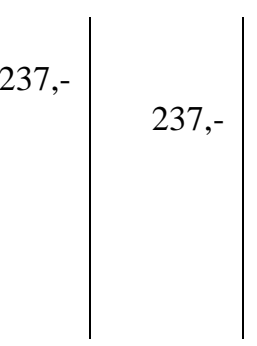

\section{b. 2012 yılı için yapılacak kayıtlar}

2012 yılına ait tanımlanmış fayda yükümlülüğünün ve dönem giderinin kaydı aşağıdaki gibi olacaktır.
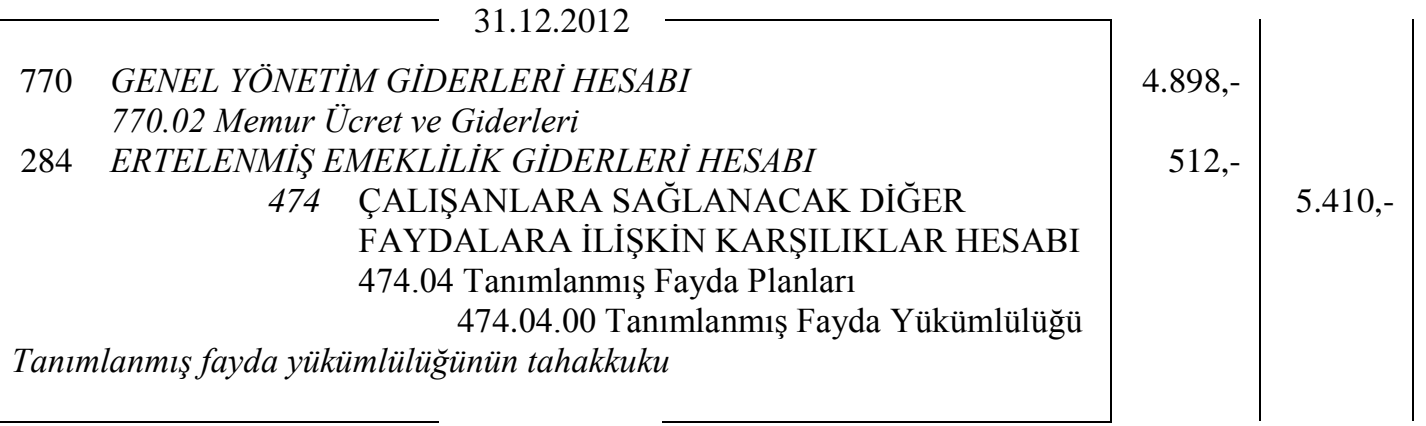

2012 yılında tanımlanmış fayda planı kapsamında gelir tablosuna aktarılacak gider tutarı cari hizmet maliyeti $(4.959,-\mathrm{TL})$ ve faiz maliyetinin $(451,-\mathrm{TL})$ toplamından plan varlıklarının beklenilen yatırım getirisinin (512,-TL) düşülmesi ile bulunacaktır. Zira TMS 19'da yer alan düzenlemelere göre; gelir tablosuna aktarılacak tutar cari hizmet maliyeti, faiz maliyeti, plan varlıklarının beklenilen yatırım getirisi gibi unsurların net toplamına göre belirlenmektedir.

“E” A.Ş.' in dönem sonunda plana yaptı̆ğ katkıların kaydı aşağıdaki gibi olacaktır.

31.12.2012

240 PLAN VARLIKLARINDAN ALACAKLAR HESABI 100 KASA HESABI

Plana yapılan katkılar

$4.784,-$

$4.784,-$ 
2012 yılında tanımlanmış fayda planı kapsamında bilançoya yansıtılacak tanımlanmış fayda borcunun tutarındaki değişim aşağıdaki gibi hesaplanarak kayda alınacaktır.

Tanımlanmış Fayda Borcundaki Değişim = Tanımlanmış Fayda Borcu (2012) - Tanımlanmış Fayda Borcu (2011)

Tanımlanmış Fayda Borcundaki Değişim = 835,-TL - 237,-TL =598,-TL

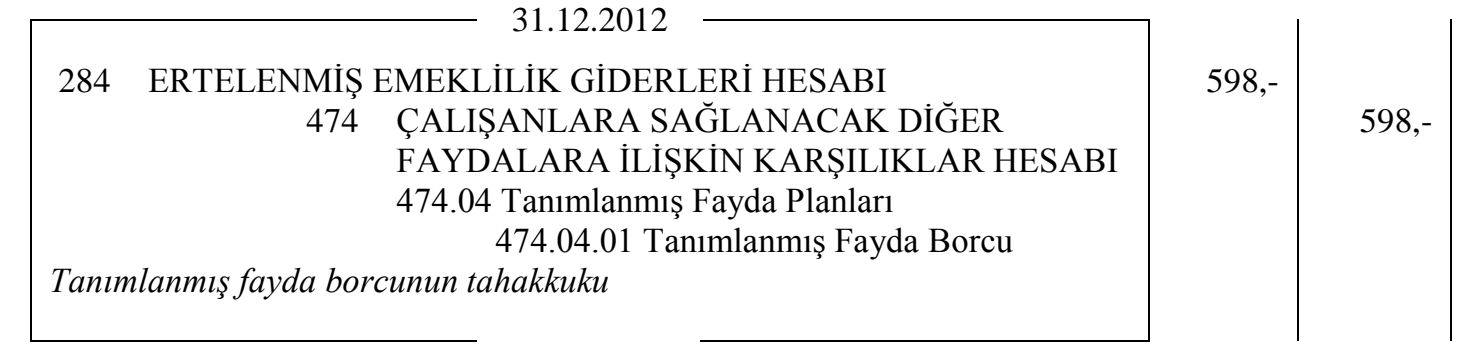

Tanımlanmış fayda borcunun yanı sıra plan varlıklarının değerinde meydana gelen artışların da dikkate alınması gerekmektedir. Nitekim 2012 yılında plan varlıklarının değerinde meydana gelen 28,TL'lik artış aşağıdaki gibi kayda alınacaktır.

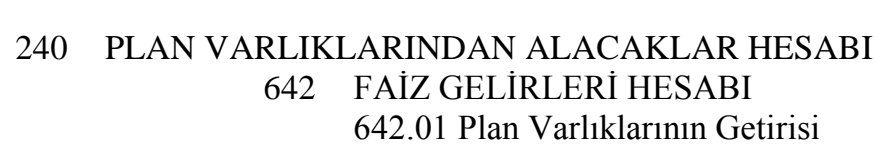

Plan varlıklarındaki artış

Aktüeryal kazanç ve kayıplar ise aşağıdaki gibi kayda alınacaktır.

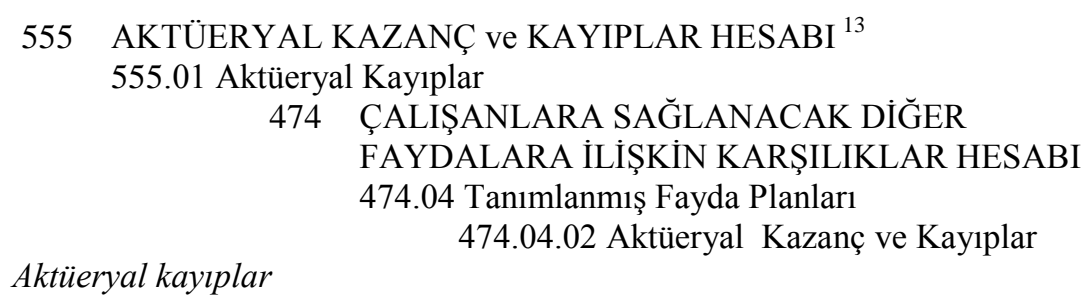

\section{c. 2013 yılı için yapılacak kayıtlar} olacaktır.

2013 yılına ait tanımlanmış fayda yükümlülüğünün ve dönem giderinin kaydı aşağıdaki gibi

\footnotetext{
${ }^{13}$ İşletmenin tanımlanmış fayda planı kapsamında ortaya çıkan aktüeryal kazanç ve kayıpların muhasebeleştirilmesinde sermaye yaklaşımı benimsediği için söz konusu kazanç ve kayıplar 555 Aktüeryal Kazanç ve Kayıplar Hesabı'nda izlenmektedir.
} 

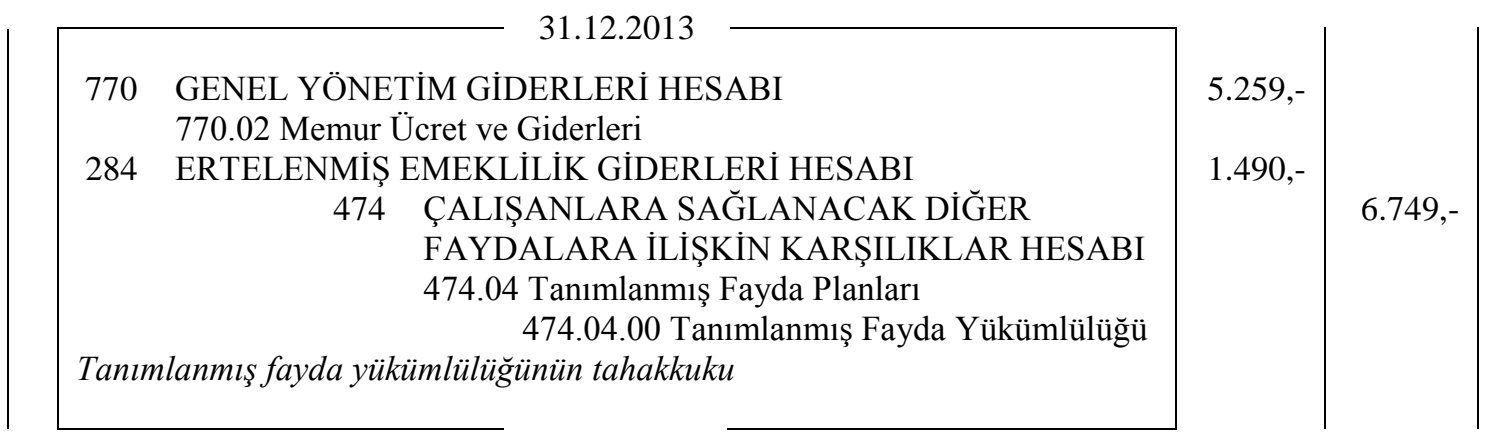

2013 yılında tanımlanmış fayda planı kapsamında gelir tablosuna aktarılacak gider tutarı cari hizmet maliyeti $(5.556,-\mathrm{TL})$ ve faiz maliyetinin $(793,-\mathrm{TL})$ toplamından plan varlıklarının beklenilen yatırım getirisinin $(1.090,-\mathrm{TL})$ düşülmesi ile bulunacaktır.

“E” A.Ş.' in dönem sonunda plana yaptı̆̆ katkıların kaydı aşağıdaki gibi olacaktır.

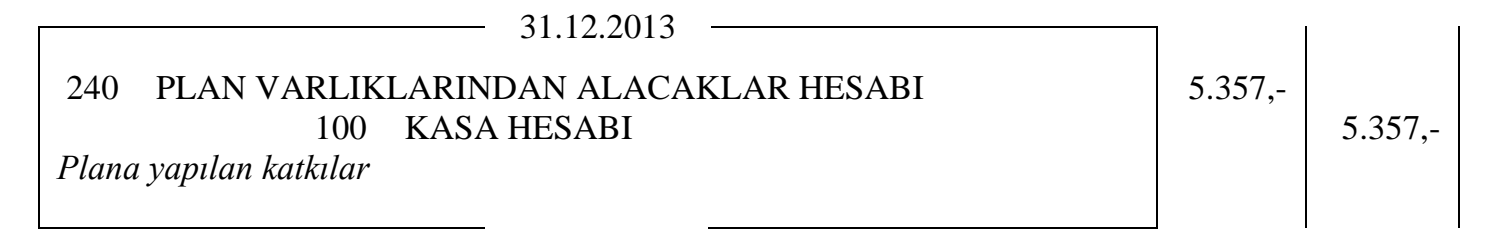

2013 yılında tanımlanmış fayda planı kapsamında bilançoya yansıtılacak tanımlanmış fayda borcunun tutarındaki değişim aşağıdaki gibi hesaplanarak kayda alınacaktır.

Tanımlanmış Fayda Borcundaki Değişim = Tanımlanmış Fayda Borcu (2013) - Tanımlanımış Fayda Borcu (2012)

Tanımlanmış Fayda Borcundaki Değişim = 927,-TL - 835,-TL = 92,-TL
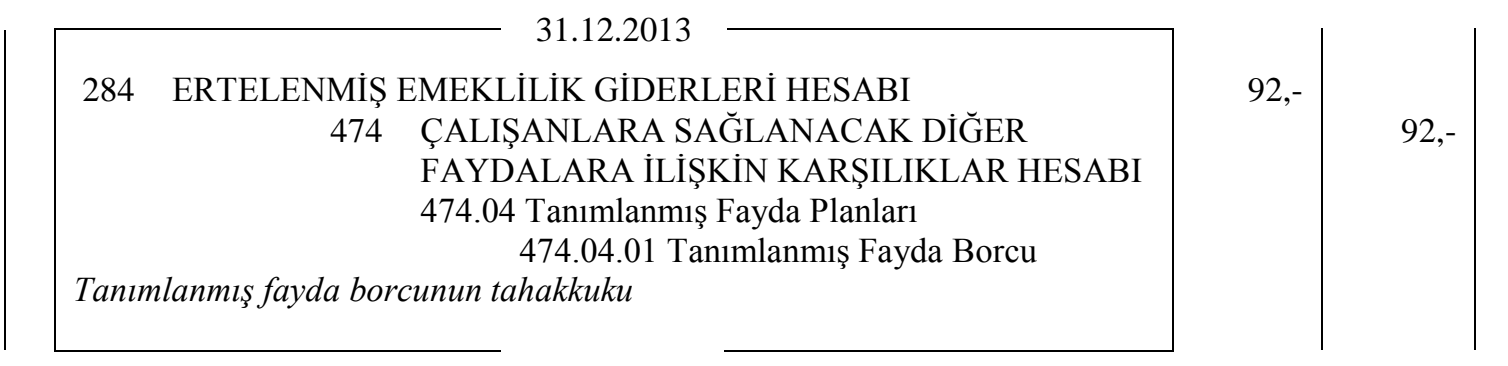

2013 yılında plan varlıklarının değerinde meydana gelen artışın da finansal tablolara aktarılması gerekmektedir. Nitekim söz konusu artış aşağıdaki gibi kayda alınacaktır.

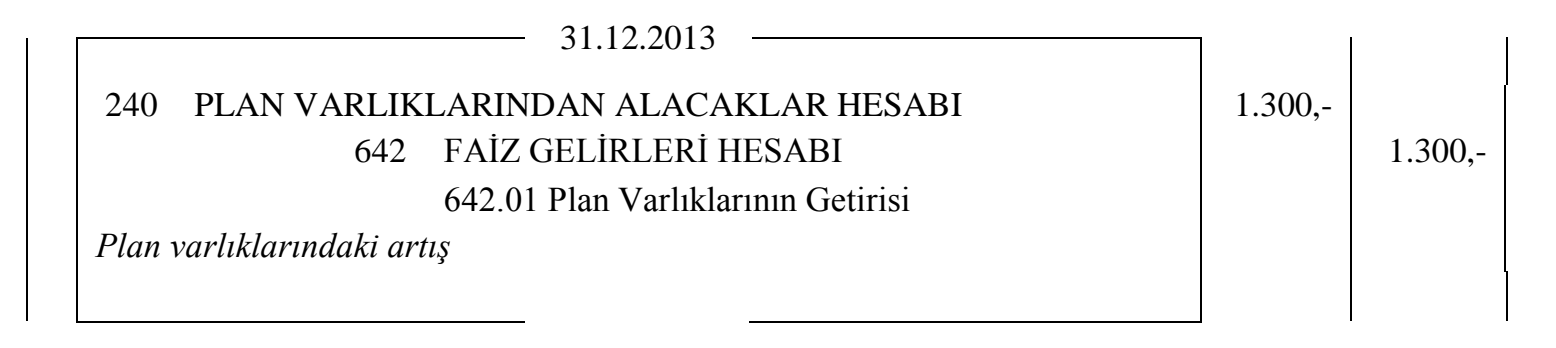


2013 yılında ortaya çıkan aktüeryal kazanç ve kayıplar ise aşağıdaki gibi kayda alınacaktır.

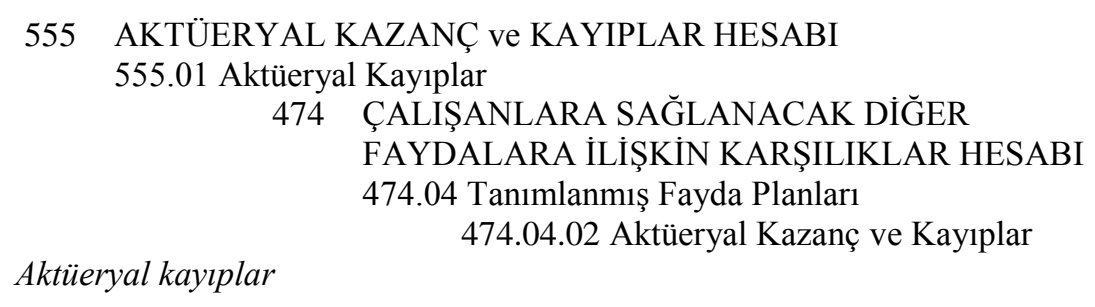

\section{d. 2014 ylı için yapılacak kayıtlar}

2014 yılına ait tanımlanmış fayda yükümlülüğünün ve dönem giderinin kaydı aşağıdaki gibi olacaktır.

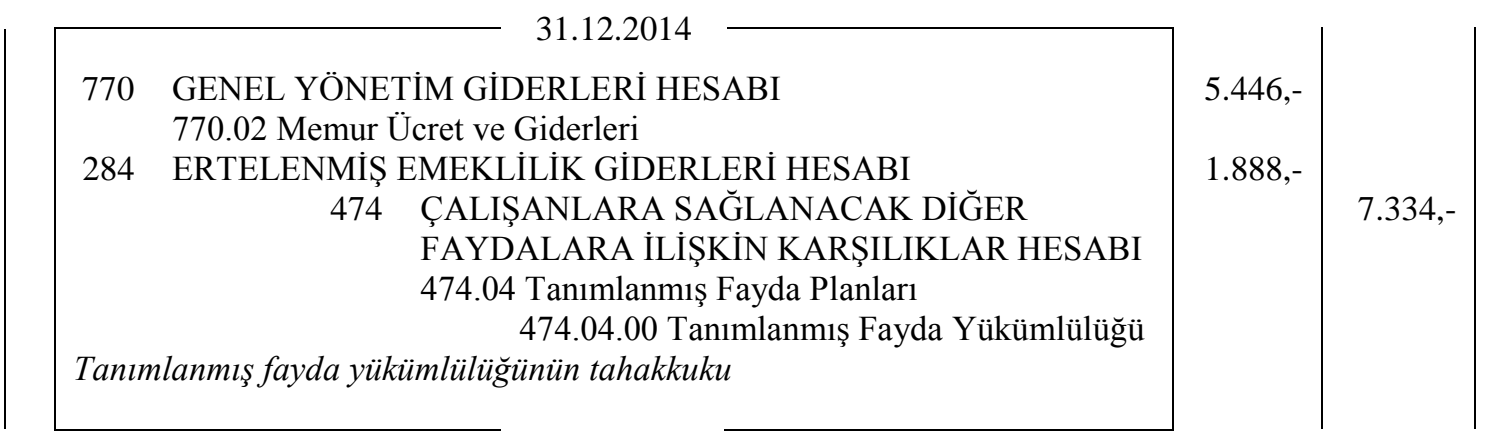

2014 yılında tanımlanmış fayda planı kapsamında gelir tablosuna aktarılacak gider tutarı cari hizmet maliyeti $(6.000,-\mathrm{TL})$ ve faiz maliyetinin $(1.334,-\mathrm{TL})$ toplamından plan varlıklarının beklenilen yatırım getirisinin $(1.888,-\mathrm{TL})$ düşülmesi ile bulunacaktır.

“E” A.Ş.’in dönem sonunda plana yaptığı katkıların kaydı aşağıdaki gibi olacaktır.

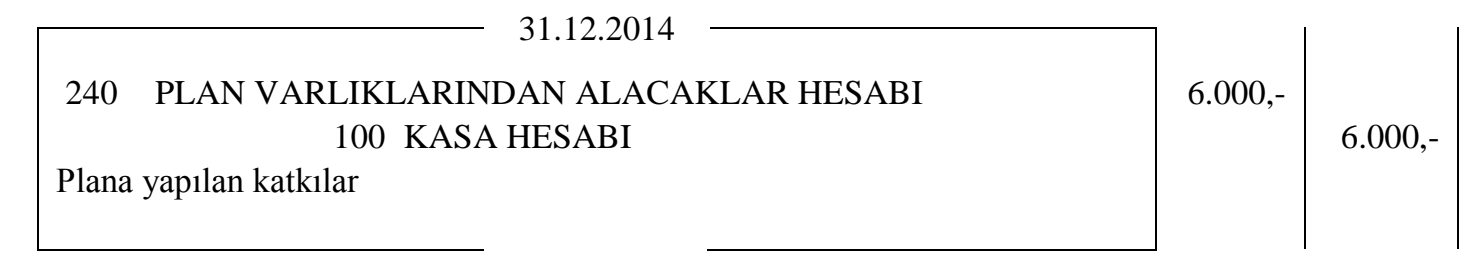

2014 yılında tanımlanmış fayda planı kapsamında bilançoya yansıtılacak tanımlanmış fayda borcunun tutarındaki değişim aşağıdaki gibi hesaplanarak kayda alınacaktır.

Tanımlanmış Fayda Borcundaki Değişim = Tanımlanmış Fayda Borcu (2014) - Tanımlanmış Fayda Borcu (2013)

Tanımlanmış Fayda Borcundaki Değişim = 379,-TL - 927,-TL= - 548,-TL 

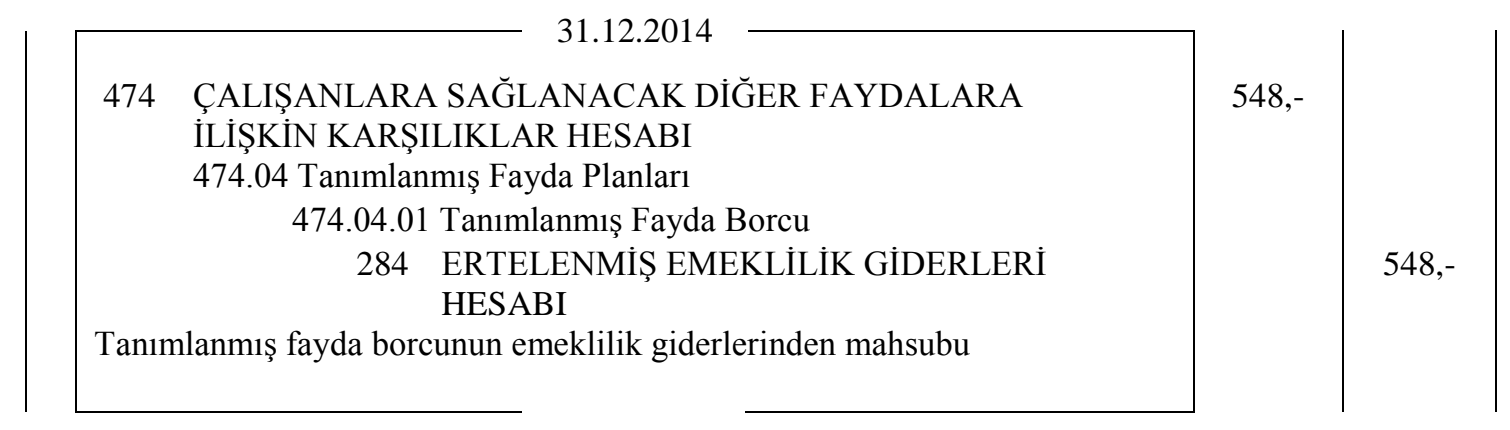

2014 yılında plan varlıklarının değerinde meydana gelen 1.882,-TL'lik artış aşağıdaki gibi kayda alınacaktır.

\subsection{2 .2014}

240 PLAN VARLIKLARINDAN ALACAKLAR HESABI

642 FAİZ GELIRLERİ HESABI

642.01 Plan Varlıklarının Getirisi

Plan varlıklarındaki artış

Aktüeryal kazanç ve kayıplar ise aşağıdaki gibi kayda alınacaktır.

\subsubsection{4}

555 AKTÜERYAL KAZANÇ ve KAYIPLAR HESABI 555.01 Aktüeryal Kayıplar

474 ÇALIŞANLARA SAĞLANACAK DİĞER

FAYDALARA İLIŞSIN KARŞILIKLAR HESABI

474.04 Tanımlanmış Fayda Planları

474.04.02 Aktüeryal Kaz. ve Kayıp.

Aktüeryal kayıplar

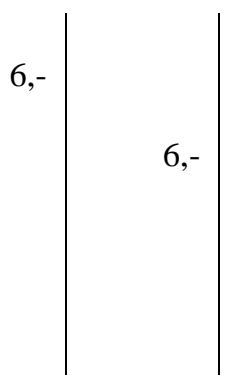

2015 yılında işletmenin fondan varlıklarını tahsil ederek tanımlanmış fayda planı kapsamında ortaya çıkan yükümlülüğünü ödemeyi planlaması durumunda dönemsellik kavramı gereğince 31.12.2014 tarihinde yapacağı kayıtlar aşağıdaki gibi olacaktır.

31.12.2014

140 PLAN VARLIKLARINDAN ALACAKLAR HESABI

240 PLAN VARLIKLARINDAN ALACAKLAR HESABI

Plandan olan alacakların vadesinin bir yılın altına düşmesi 31.12.2014

184 ERTELENMISS EMEKLİLİK GİDERLERİ HESABI

284 ERTELENMIŞ EMEKLİLIK GIDERLERİ HESABI

Ertelenen emeklilik giderlerinin kısa vadeye aktarllması

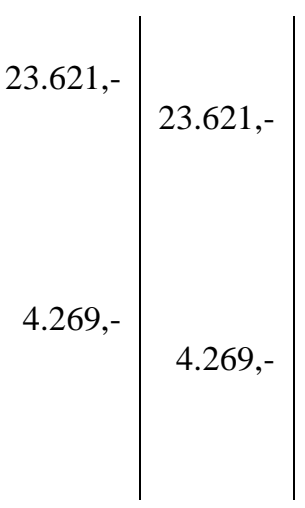


31.12 .2014

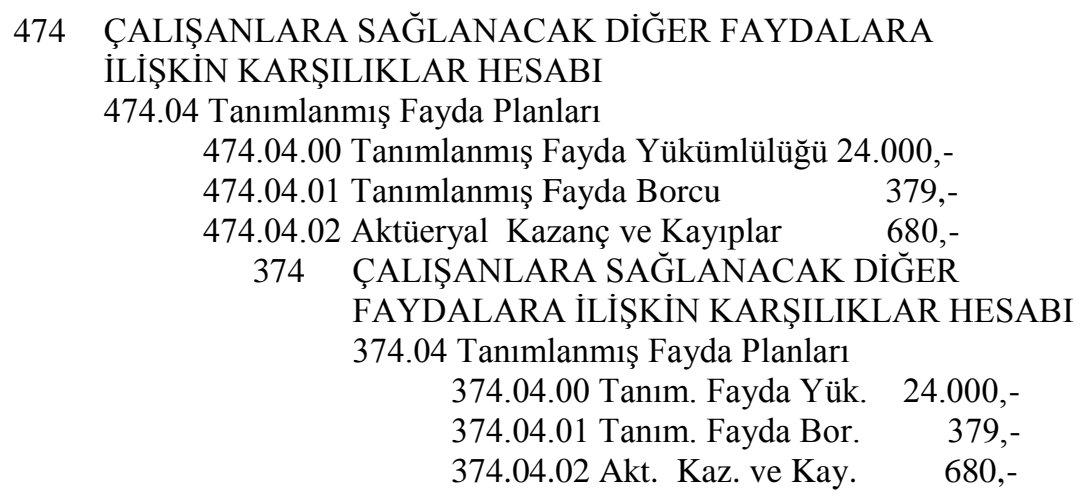

07.01.2015 tarihinde tanımlanmış fayda planı ile ilgili yükümlülüklerin karşılanması amacıyla fona aktarılan varlıkların tahsil edilerek yükümlülüğün ödenmesi durumunda işletme tarafından yapılacak kayıtlar aşağıdaki gibidir.

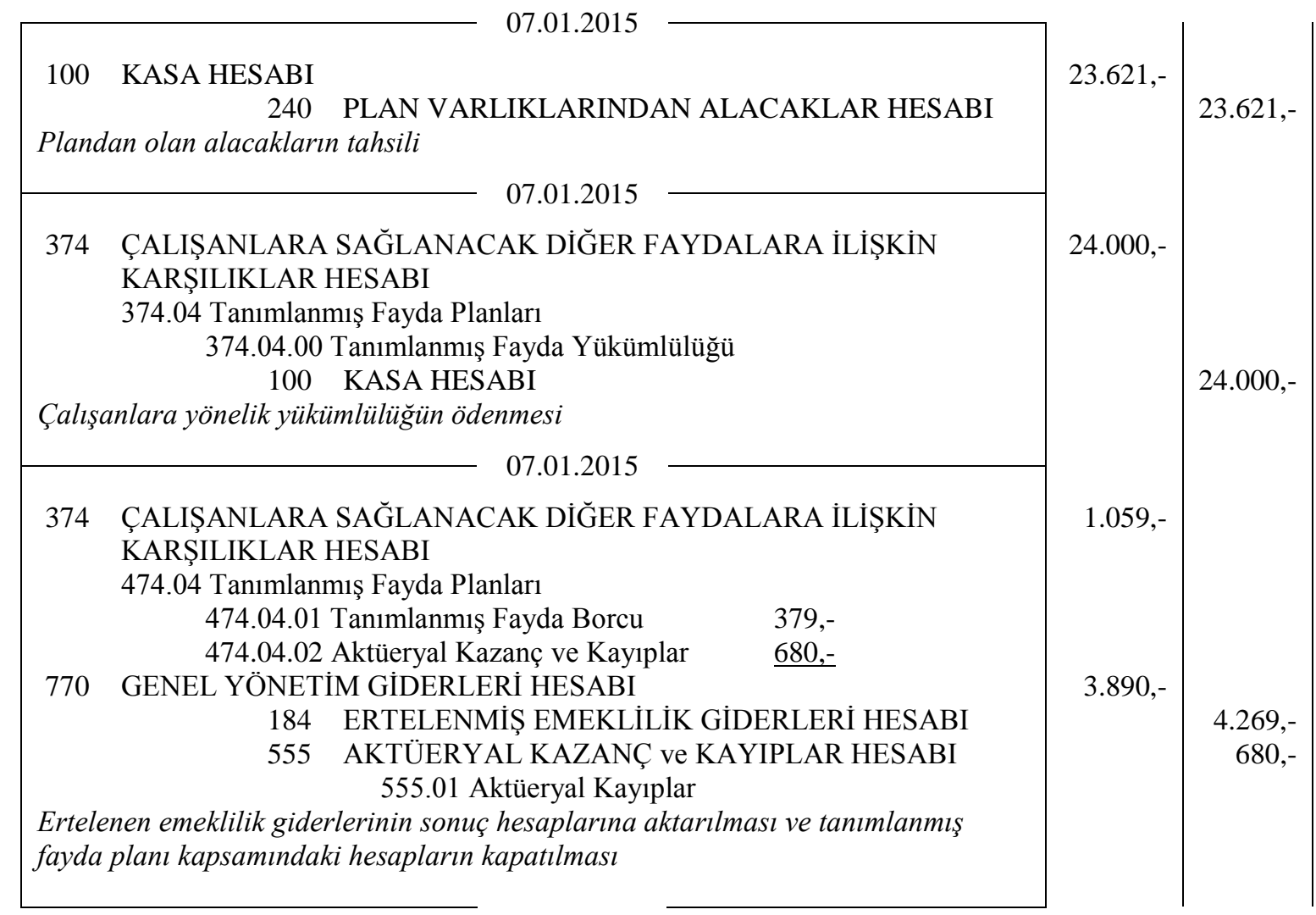

Yukarıdaki kayıttan da anlaşıldığı üzere işletme 2011 yılında oluşturduğu tanımlanmış fayda planı kapsamında ortaya çıkan 24.000,-TL'lik yükümlülügünü yerine getirmiş ve daha önceki dönemlerde giderleştiremediği emeklilik giderlerini (3,890,-TL) sonuç hesaplarına aktarmıştır. 


\section{SONUÇ}

Tanımlanmış fayda planlarında ise işletmenin yükümlülüğü çalışanlara gelecekte ödenecek olan faydaların bugünkü değerine göre hesaplanmaktadır. Tanımlanmış fayda planıyla ilgili yükümlülükler, genellikle çalışanın hizmetinden çok sonra yerine getirildiğinden iskonto edilerek ölçülmekte ve yapılacak ölçümde aktüeryal varsayımlar kullanılmaktadır. Bu durum, tanımlanmış fayda planlarının finansal tablolara aktarılmasını karmaşı hale getirmektedir. TMS 19 söz konusu karmaşıklı̆̆ın olumsuz etkilerini azaltmak için muhasebe sisteminde basitleştirilmiş varsayımlar ve yöntemler kullanarak gelecekteki yükümlülüklerin ölçülmesi amacıyla sistematik bazı işlemlerin yapılmasını dolayısıyla da bu işlemlere bağlı olarak bilanço ve gelir tablosunda raporlanması gereken değişik unsurları ifade etmiş ve konuya yönelik ayrıntılı düzenlemelere yer vermiştir.

Tanımlanmış fayda planı kapsamında, her dönem sonunda bilançoya yansıtılacak fayda yükümlülügünün belirlenmesinde çalışanın gelecekteki maaşı, işten ayrılma oranı, ölüm oranları, iskonto oranı gibi birçok faktör etkili olduğundan aktüeryal varsayım ve değerleme yöntemlerine ihtiyaç duyulmaktadır. Zira çalı̧̧anların demografik özellikleri ile piyasalarda geçerli olan finansal özelliklere ait unsurları içeren aktüeryal varsayımlar, tanımlanmış fayda yükümlülüklerinin aktüeryal değerlemesinde dikkate alınmaktadır. Aktüeryal değerleme yöntemi olarak ise tanımlanmış fayda yükümlülüğünün bugünkü değerinin belirlenmesinde öngörülen yükümlülük yöntemi kullanılmaktadır. Sözkonusu yöntem ile işletmenin tanımlanmış fayda planı kapsamında çalışanlarına gelecekte sağlayacağı faydalara yönelik yükümlülüğü çalışanın hizmet süresiyle ilişkilendirilmekte olup böylece her bir dönem için bilanço ve gelir tablosuna aktarılacak tutarlar tespit edilmektedir.

Tanımlanmış fayda planı kapsamında yükümlülüklerin yanı sıra işletmenin muhasebe politikasına bağlı olarak aktüeryal kazanç ve kayıpların bilançoya yansıtılması da mümkün olmaktadır. Zira TMS 19 tarafından, genel anlamda aktüeryal varsayımlar ile gerçekleşen durum arasındaki farklara bağlı olarak ortaya çıkan aktüeryal kazanç ve kayıpların kayda alınmasına yönelik sermaye yaklaşımı ve koridor yaklaşımı gibi alternatif yöntemler geliştirilmiş ve bunların kullanımıyla ilgili işletmelere seçimlik bir hak sunulmuştur. Buna göre, örneğin, işletmelerin tercihini sermaye yaklaşımından yana kullanması durumunda aktüeryal kazanç ve kayıplar doğrudan doğruya özkaynaklar hesap sınıfında dolayısıyla da bilanço içinde izlenmiş olacaktır. Koridor yaklaşımında ise aktüeryal kazanç ve kayıplar plan varlıklarının gerçeğe uygun değeri ile tanımlanmış fayda yükümlülügünün bugünkü değerinden büyük olanının \%10'unu göre belirlenen sınırı aşması durumunda sınırı aşan kısım gelir tablosunda kayda alınabilmektedir.

İşletmeler koridor yaklaşımı çerçevesinde aktüeryal kazanç ve kayıpların gelir tablosunda kayda alınmasında farklı tercihlerde de bulunabilmektedir. Buna göre işletmeler tanımlanmış fayda yükümlülügünün bugünkü değeri ile plan varlıklarının gerçeğe uygun değerinden daha büyük olanının \%10’unu aşan aktüeryal kazanç ve kaybın, tamamını veya bir kısmını ortaya çıktığı dönemde kayda 
alabileceği gibi \%10 sınırı içinde olup olmadığına bakmaksızın tamamını da gelir tablosuna aktarabilecektir.

Tanımlanmış fayda planları kapsamında aktüeryal kazanç ve kayıpların yanı sıra gelir tablosunu ilgilendiren cari hizmet maliyeti, faiz maliyeti, plan varlıklarının beklenen yatırım getirisi, geçmiş hizmet maliyeti gibi bazı unsurlar da ortaya çıkmaktadır. Söz konusu unsurlardan cari hizmet maliyeti ile faiz maliyeti gider; geçmiş hizmet maliyeti ve plan varlıklarının beklenen yatırım getirisi ise duruma göre gider veya gelir özelliği taşımaktadır. Nitekim cari hizmet maliyeti çalışanın hizmetine karşılık içinde bulunulan dönemde kazanılan fayda tutarını; faiz maliyeti ise cari hizmet maliyetine bağlı olarak ortaya çıkacak faydanın çalışanın işten ayrılacağı süreye kadar her yıl iskonto oranına göre yeniden değerlenmesi durumunda meydana gelen artışı gösterdiğinden işletme açısından gider olarak değerlenmektedir. Buna karşılık plan varlıklarının beklenen yatırım getirisi, fona aktarılan varlıkların yatırımlarda değerlendirilmesinden kaynaklanan kazanç ve kayıplara; geçmiş hizmet maliyeti de cari dönemde emeklilik planlarında yapılan düzenlemeler sonucu tanımlanmış fayda yükümlülüğünün bugünkü değerinde olumlu ya da olumsuz değişimlere göre belirleneceğinden gider veya gelir olarak nitelendirilecektir.

Sonuç olarak TMS 19, mevcut uygulamalardan farklı olarak, işletmelerdeki insan kaynaklarının değerinin kısmen de olsa muhasebe hesaplarına (374 veya 474 nr.lı hesaplar) aktarılmasına ve böylece daha gerçekçi bilgiler sunan finansal tabloların hazırlanmasına imkan sağlamaktadır. Örneğin şu an fayda planı kapsamında uygulanan kıdem tazminatları, mevcut hükümlere göre geçmiş verileri dikkate alarak hesaplanırken, TMS 19'a göre ise gelecekteki verileri kullanarak hesaplanmakta ve bu yolla da çalışanın işletme için değeri daha doğru hesaplanmaktadır.

\section{KAYNAKÇA}

Akdoğan, N. ve Sevilengül, O. (2007) "Türkiye Muhasebe Standartlarına Uyum için Tekdüzen Hesap Planında Yapılması Gereken Değiş̧iklikler”, Mali Çözüm Dergisi, 84: 29-70.

Akpınar, O. (2007) "Bireysel Emeklilik Sistemi ve Türkiye'deki Emeklilik Yatırım Fonlarının Performans Çözümlemesi”, Yüksek Lisans Tezi, Kocaeli Üniversitesi, Sosyal Bilimler Enstitüsü, Kocaeli.

Amen, M. (2007) “Simulation-Based Comparison of Existent IAS 19 Accounting Options", European Accounting Review, 16(2): 243-276.

Arslan, Y. (2012) “TMS 19: Çalışanlara Sağlanan Faydalar Standardı”, Vergi Dünyası, 368: 124-133.

Belkaoui, A. R. (1998) “Critical Financial Accounting Problems: Issues and Solutions”, London, Quorum Books.

Çakıroğlu, B. C. (2006) "Faydası Belirli Özel Emeklilik Sistemleri ve Optimal Dağıtım Periyodu Modellemesi”, Yüksek Lisans Tezi, Hacettepe Üniversitesi, Fen Bilimleri Enstitüsü, Ankara. 
Derelioğlu, D. (2001) “Türkiye'de Özel Emeklilik Fonu Uygulamaları”, Türkiye Genç İş Adamları Derneği (TÜGİAD), Ankara.

Elliott, B. ve Elliott, J. (2007) "Financial Accounting and Reporting”, 11th Ed., England, FT Prentice Hall.

Epstein, B. J. ve Mirza, A. A. (2005) "Wiley IFRS 2005: Interpretation and Application of International Accounting and Financial Reporting Standards”, New Jersey, Wiley.

FEE - Federation Des Experts Comptables Europeens (2001) "How European Companies Are Applying IAS 19 (Revised) on Pension Accounting in the First Year of Application”, Bruxelles.

Gençoğlu, Ü. G. (2007) “Türkiye Muhasebe Standartları ve Uygulamalar”, İstanbul: Türkmen Kitabevi.

Holt, G. (2007) "IAS 19: Employee Benefits", Student Accountant, www.accaglobal.com/pubs/students/publications/.../Holt0107.pdf, (15.09.2010).

Lacomba, J. A. ve Lagos, F. (2009) "Defined Contribution Plan vs. Defined Benefits Plan: Reforming the Legal Retirement Age", Journal of Economic Policy Reform, 12(1): 1-11.

Lewis, R. ve Pendrill, D. (2004) "Advanced Financial Accounting”, 7th Ed., England, FT Prentice Hall.

Lind, M. S. (2006) "Defined Benefit Pensions: Funding and Asset Allocation Choices", Doktora Tezi, The University of Texas, Texas.

Morais, A. (2010) “Actuarial Gains and Losses: The Determinants of the Accounting Method”, Pacific Accounting Review, 22(1): 42-56.

Örten, R., Kaval, H. ve Karapınar, A. (2007) “Türkiye Muhasebe-Finansal Raporlama Standartları”, Ankara: Gazi Kitabevi.

Rodgers, P. (2007) "International Accounting Standards”, England, ELSEVIER and CIMA.

Şahin, R. D. (2010) “Aktüeryal Kıdem Tazminatı Karşılığı Hesaplamaları”, Akademi Aktüerya, 1(1): 9-14.

Şirin, İ. (2005) "Emeklilik Planlarında Fon Varlıklarının Aktüeryal Değerlemesi”, Yüksek Lisans Tezi. Hacettepe Üniversitesi, Fen Bilimleri Enstitüsü, Ankara.

Van Greuning, H. (2009) "International Financial Reporting Standards: A Practical Guide”, 5th Ed., Washington: World Bank Publication.

Zelinksy, E. A. (2009) "The Aftermath of the Cash Balance Controversy: Applying the ContributionBased Test for Age Discrimination to Traditional Defined Benefit Pensions", Virginia Tax Review, 29(1): 1-28. 